Portland State University

PDXScholar

1975

\title{
An exploration of the feelings and attitudes of women separated from their children due to incarceration
}

Dorothy Lundberg

Portland State University

Ann Sheekley

Portland State University

Therese Voelker

Portland State University

Follow this and additional works at: https://pdxscholar.library.pdx.edu/open_access_etds

Part of the Child Psychology Commons, Other Psychology Commons, and the Social Work Commons Let us know how access to this document benefits you.

\section{Recommended Citation}

Lundberg, Dorothy; Sheekley, Ann; and Voelker, Therese, "An exploration of the feelings and attitudes of women separated from their children due to incarceration" (1975). Dissertations and Theses. Paper 1826. https://doi.org/10.15760/etd.1825

This Thesis is brought to you for free and open access. It has been accepted for inclusion in Dissertations and Theses by an authorized administrator of PDXScholar. Please contact us if we can make this document more accessible: pdxscholar@pdx.edu. 
AN EXPLORATION OF THE FEELINGS AND ATTITUDES

OF WOMEN

SEPARATED FROM THEIR CHIIIREN DUE TO INCARCERATION

By

Dorothy Lundberg

Ann Sheekley

Therese Voelker

A practicum submitted in partial fulfillment

of the requirements for the degree of

MASTER OF SOCIAI. WORK

PORTIAND STATE UNIVERSTTY

1975

Approved:

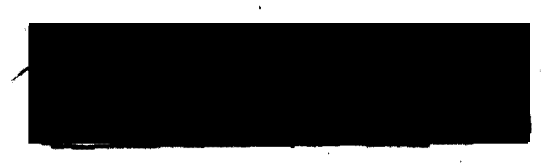

June Dunn, M.S.W.

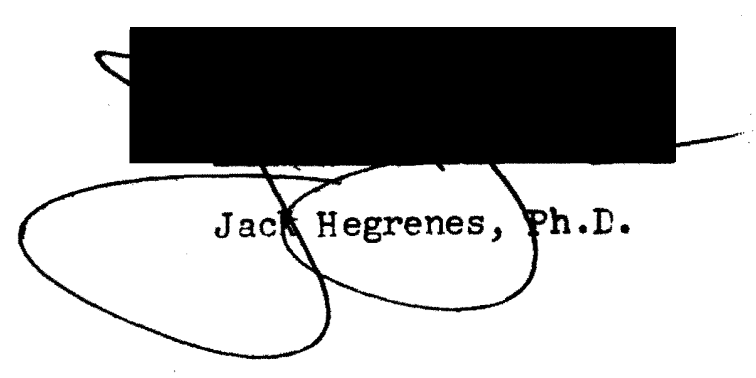


TABLE OF CON TENTS

PAGE

I.IST OF TABLES 1

ACKNOWLEDGMENTS $\quad$ it

INTRODUCTION AND RESEARCH ISSUE iii

CHAPTER

I THEORETICAL FRAMEWORK I

II RESEARCH METHODOLOGY

IJT DESCRIPTION OF THE SETTING

$\begin{array}{ll}\text { IV RESEARCH RESULTS } & 17\end{array}$

Description of the Population $\quad 17$

Attitudes and Feelings Related to
Separation from Children

$V$ ANALYSIS OF THE IATA 33

Priority of the Mother Role 33

Evidence of Mother-Child Attachment 38

Indications of Grief and Loss 40

Effects of Imprisonment on MotherChild Bond. 49

Review of the Prison Supports in

Maintaining the Mother-Child Bond 53

Conclusions $\quad 58$

VI RECOMMENDATIONS AND TMPLICATIONS FOR
FURTHER RESEARCH

FOOTNOTES AND REFTRENCES 66

RIBITOGRAPHY $\quad 69$

APPENDICES $\quad 74$ 
I Percentage of Women Who Have Children in Various Age Groups

II Types of Jobs Most Widely Held by Respondents

III Priority of Concern $\quad 22$

IV Modes of Communication 25

$\nabla$ Frequency of Specific Emotions Elicited Through Separation

VI Frequency of Referents $\quad 28$

VII Emotions with Frequency of Referent 28

VIII Separation Concerns $\quad 30$

IX Quality of Visit---Activity Taking Place 31

$X$ Difference Between Being at Home with Child and Prison Visit 31

XI Mother's Feelings After Visit with Child 31

XII Mother's Perception of Effect of Separation from Children on Parenting Ability 32

XIII Mather's Perception of Major Problems Arising From Separation 


\section{ACKNOWLEDGMEN TS}

Sincere appreciation is expressed to Dr. Jack Hegrenes and June Dunn who, as our advisors from the School of Soclal Work, gave of their time and energies and who were supportive and encouraging.

Special thanks are due to Jerry Blake and members of the National Criminal Justice Graduate Research Fellowship Program for their assistance in formulating this project, and whose guidance and understanding were v1tal in 2$] 1$ phases of the research.

Gratitude is expressed to Mr. Thomas Toombs, Superintendent, and Mr. Curt Fiesel, Children's Services Divison Iiaison Worker, for allowing us to conduct the research at the Oregon Women's Correctional Center. We realize that there is still some reluctance to permit general descriptive studies which focus on aspects of imprisonment selected by the researchers rather than on administrative ends suggested by the prison, and we appreciate the opportunity to do research in this sensitive area.

Finally, we would like to thank the women who participated in our study. Their willingness to share with us their feelings and attitudes regarding their separation from their children was by far the most rewarding aspect of this research. 
TIIS STUDY WAS SUPPORTED BY GRANTS FROM THE COMMNITY HEALTH PROJECT OF THE SCHOOL OF SOCIAL WORK AND THE NATIONAL CRIMINAI, JUSTICE GRADUATE RTSEARCH FELIOWSHIP PROGRAM OF PORTLAND STATE UNIVERSTTY. THE CONTENTS, HOUEVER ARE IN NO WAY THE RESPONSIBILTTY OF EITHER PROJECT. 


\section{INTRODUCTION AND RESEARCH ISSUE}

Although significant research has shed light on what happens to children when they are removed from their parents, few studies have explored the effects on parents undergoing separation from their children. Iiscussions tend to be confined to separate dimensions exploring child's needs on one side and parental obligations on the other. Much of the planning and prolonged care provided for children in placement reflects a traditional child-centered focus. This has led to a lack of attention to parental needs, and a gross ignorance about their lives, feelings and aspirations.

When women are involuntarily separated from their children through incarceration, a more complex disruption between parent and child occurs. There is little systematic research done on the unique nature and meaning of this separation to mothers. With this in mind, the focus of this descriptive study has been on the exploration of feelings and attitudes of imprisoned mothers regarding enforced separation from their child ren and the effects of imprisonment on their maternal role. 
CHAPTER I

\section{THEORETICAI FRAMEWORK}

Removal and confinement have long been a means of social control for the deviant member of society. Past emphasis on punishment, ranging from physical labor and abuse to severe deprivation and death, has declined in Criminal Justice programs. The goals of prisons and corrections in the United States now attempt to combine provision for the protection of society as well as improving the social functioning of the offender.

Despite progress toward a more humanized system emphasizing "rehabilitation", incarceration for most serious offenders entails painful deprivation. Sykes maintains that there are five areas contributing to the "pains of imprisonment": "I) loss of freedom and social acceptance; 2) loss of material comforts and personal belongings; 3) loss of heterosexual relations and family and friends; 4) 1oss pf personal autonomy and responsibility; and 5) loss of personal security and pri vacy."1

Most research focuses on the nature of inmate culture and social organization of the male prison in response to these stated deprivations, as well as assessing the effectiveness of the "rehabilitation" programs. This would correspond to the fact that there are approximately 18 men to 1 woman in county jails and 30 men to 1 woman in state and federal prisons. 2

Though both men and women prisoners experience the same kinds of 
deprivation, the nature of the response to the "pain" of imprisonment may be different. Male and female inmate cultures are influenced by the manner in which roles and values are defined in the larger society. At this time in the United States, there is questioning of traditional sex role expectations. Despite the broadening of alternatives to women, those who bear children are constrained by the sheer amount of time involved in meeting the role responsibilities of being a housekeeper and mother. The social structure of the prisons for women reflects a significant role difference from that of male prisoners. Though both experience primary problems of self adjustment in the institutional confinement, the most severe deprivation for the woman is her loss of the maternal role. 3 Separation from her children and family represents a painful and central anguish.

\section{THE SEPARATION EXPERIFNCE}

When physical separation occurs between two people with pre-existing attachment to each other, there are reciprocal feelings experienced. Separation reactions have been viewed in literature in terms of divorce, hospitalization, institutionalization, foster placement and other such crises, including the ultimate of death. Generally, the responses on both sides of the severed relationship reveal remarkably similar affective patterns.

Bowlby describes three basic stages in the process of separation. 4 The initial stage of protest is one of primary anxiety in reaction to the danger of losing a loved one. In the second phase, a critical stage of despair includes the pain of mourning in reaction to the actual loss of 
object. It is this acute level of development which has prompted much discussion in unfolding the symptomatology of grief relevant to different separation crises. Iindemann's classic description of symptoms: 1) somatic distress; 2) idealization of the relationship; 3) guilt and 4) hostile reactions ${ }^{5}$, varles only slightly from Kübler Ross' 1) denial and isolation; 2) anger; 3) bargaining and 4) depression. 6 Bowlby's third and final phase finds support from most writers, including those mentioned, in noting the experience of detachment or acceptance, be it a healthy resolution or a pathological adaptation, involving a consolidation of defenses to cope with the pain of separation.

Substantial attention has been given to the grief symptoms of children when separated from parents and/or siblings. Freud, Spitz and Bowlby emphasize the effect of matemal deprivation on the emotional and personality growth of a child, particularly in the first three years.7 Goldstein, et. al. In Beyond the Best Interests of the Child, advocate a child's need for unbroken continuity of affection and stimulating relationship with a significant adult. They particularly point out the child's sense of time, in that separation beyond two months for a child under the age of five years is beyond comprehension. 8

Dxamination of the meaning of separation to parents has been less systematically explored, though recent studies of parents dealing with a dying child have been initiated. Parents experiencing the stages of grief and loss when their child is placed outside the home have revealed feelings of guilt and inadequacy, 9,10 and isolation and emptiness.11,12 Shirley Jenkins has extensively studied the area of filial deprivation when children are in foster care and found a wide range of painful 
emotive responses. 13

The significance of the reciprocity of the grief reaction is not to be underestimated in attending to the separation between mother and child. The response to separation on both sides involves a complex process influenced by its nature and duration, the quality of the attachment bond before the experience, the age and stage of development of the child, the respective ego strengths, environmental stress, general biological capacities, as well as the emotional conflicts both are undergoing. 14

Therese Benedek emphasizes the mutuality of communication in normal parenting and the concept of a "psychic economy", the balance of which depends on the outcome of the mother's imer conflicts and her response to the needs of her child. 15 When separated from her child, unless the mother hạs begun to process her feelings and needs in her grief process, she will not be adequately prepared to respond to her child when reuntted. Jenkins points out that a mother's unresolved pain will only reinforce that trauma suffered by her child in the separation experience.16 The heightened tension from the child, described by Bowlby and others, can only bring about pressure upon the parent as she feels both her own and the child's frustrated needs. If she fails in balancing this "psychic economy", her resulting feelings of guilt intensify her sense of conflict and helplessness while the child feels rejected and abandoned. 17

It is at this point that a complex system of defense mechanisms emerge in both parent and child to lower the discomfort, support self esteem and prevent personality disintergration. Luring separation, when the mutuality of communication has been broken, various defenses and coping patterns are used to support and murture the respective mother and child. The critical issue is at the time of reunion of mother and child 
as to how rigid and permanent the two individuals have internalized their defenses, preventing a healthy return and adjustment to an emotionally close relationship.

In light of the stated dynamics of the mother-child relationship during separation, the importance of a mother processing her grief becomes extremely apparent. The vulnerability of a young child predisposes him to a more serious disturbance with the loss of a significant acult. The degree to which the mother is able to give of herself in provicing nurturing care when reunited with her child, is determined by the extent to which she adaptively resolved her own pain.

Research with mothers in prison in regard to their separation experience has been largely neglected. There has been recent interest and study of the woman in prison, examining her social roles and needs.18,19,20,21 According to a study by the American Association of University Women, prepared by the Pennsylvania Division, approximately 70 to 80 percent of women incarcerated have children whom they support.22 It seems reasonable that in order to plan for a woman while in prison, it is important to consider her familial as well as her societal roles. Zalba, 23 Eyman, 24 and Burkhart 25 express concern for cohesive familyoriented planning and need for services for a mother's needs. Thus far, though, there has been to our knowledge no formal exploration of the feelings and attitudes involved in the separation experience unique to mothers who have been forcibly separated from their children due to imprisonment.

Because of lack of information in this area, this project took on the form of a descriptive, exploratory study. Objectives of the research included: 1) exploration of the feelings and attitudes of mothers in 
prison toward separation from their children; 2) exploration of the effects of imprisomment on the mother-child relationship as reflected in the mother's concern and involvement; and 3) examination of the prison system supports in maintaining the legal rights of the mother-child bond.

\section{IEGAI RIGHTS OF MOTHERS}

In many instances, cultural roles are reinforced by law. In order to provide a basis for this study, the legal rights of parents cannot he discounted. The attributes "biological" or "natural" in common usuage designate the parents who have actually produced the child. This blood tie is respected by the legal system and parental rights include possession of the child. This right is confirmed by a birth certificate and is not invalidated unless the child is neglected and the parents are found to be unfit or unless the adults choose to give the child up for adoption. Therefore, unless the court terminates parental rights, they remain intact even for the duration of a separation due to incarceration. (see appendix E) 


\section{GHAPTER II}

\section{RESEARCH METHODOLOGY}

\section{Selection of Institution}

The Oregon Women's Correctional Center was selected for this study because it is the major correctional facility in the state, and because it has a relatively stable population. It was chosen over other institutions, such as Multnomah County Jail at Rocky Butte, because the women at OWCC are confined for a longer period of time. It was felt that a state institution where the average time of incarceration is thirteen months would afford a more focused description of the residents' feelings and attitudes about involuntary separation.

\section{Contact With Prison Officials}

Contact with prison officials occurred in three stages. Initially the researchers met with $\mathrm{Mr}$. Thomas Toombs, Superintendent, and $\mathrm{Mr}$. Curt Fiesel, Children Services Division Liaison Worker, to discuss the possibility of conducting a research project at the Center. Subsequent meetings regarding plaming and data collection were held with $\mathrm{Mr}$. Flesel. Final contact with the prison involved interviews with $\mathrm{Mr}$. Toombs and Mr. Fiesel regarding their perceptions about their roles in the correctional setting as well as their feelings about rehabilitation.

\section{Data Collection}

The data were collected by use of an interview schedule. (appendix B) 
The final form of the interview schedule was devised after pretesting at the YWCA Prison Project in Portland, Oregon. Prior to the pretest all relevant material related to the topic was reviewed to ascertain what content the interview should include. The researchers also consulted with Ms. Dorothy Baker, M.S.W. of the YWCA Prison Project for the additional input. After the pretest the women who participated in the interview made comments and suggestions, some of which were incorporated in the final form of the interview schedule.

The interview schedule was constructed to collect data in three major areas: 1) demographic information, 2) attitudinal information about feelings regarding their separation from their children, and 3) information related to the women's perception of the prison's role in facilitating the maintenance of their relationship with their children.

The interview schedule administered via a personal one-to-one interview was the only source of data collection. The superintendent indicated that the residents' personal files could be made available for items related to social history but the researchers chose not to use them and to rely solely on the data as gained through the questionnaires.

An interviow schedule was used to maximize the respondents' involvement. Additionally, due to the sensitive nature of the subject matter, the researchers viewed the interview schedule as a means of eliciting personal information within a supportive framework.

\section{Sampling}

At the time the research was conducted there were 61 residents of 
which 39 were mothers. From a population of 39 mothers, 34 volunteered to participate in the study (89 percent). Mr. Flesel informed the women shortly before the interviews began that three gracuate students from Portland State University would be coming to the Center to interview mothers about their feelings about being separated from their children and he emphasized the voluntary nature of their participation. After the interviews began, Mr. Fiesel's role involved informally scheduling the residents for their interviews. Each interviewer was given a separate room to conduct the interview and when the interview was completed, the interviewee or $\mathrm{Mr}$. Fiesel would send in the next subject.

\section{Interview Procedure}

When the interviewee presented herself, she was given an introductory explanation, (appendix A) and was asked if she had any questions. It was decided beforehand that due to the nature of the questions and the need for rapport that the researchers would be fairly open in their approach to the interview. Since the questions were quite subjective, the interviewee was allowed to digress briefly if she felt the need to respond to more than the stated question.

\section{Quantification of the Data}

The interview schedule was composed of free-answers or "open" questions and probes. Therefore the data had to be converted into numerical form. Each question was given a classification scheme or "coding frame". Initially there were a large mumber of coding frames that were later collapsed. Since the main purpose was description along with the use of correlation between certain variables, the researchers 
did not feel they lost any significant information by collapsing the classification schemes. Raw data was used in the computation of demographic information (age, number of children, marital status etc.).

\section{Follow-up Interview with Prison Officials}

Although the main thrust of the data collection was confined to interviewing the residents, the researchers felt it was important to interview the administrators as well. (appendix c) Several weeks after interviewing the women the researchers returned to the Correctional Center to interview Mr. Thomas Toombs and Mr. Curt Fiesel. The main objective was to obtain their perspective on many of the issues raised in the responses of the women who were interviewed. Interview topics included: job description, goals of rehabilitation, the function of the parole board and future trends related to women in the criminal fustice system. The data collected in these interviews was used in the description of the setting and in the analysis of the results. 
GHAPTER III

THE SETTING

Founded in 1965, Oregon Women's Correctional Center is a maximum security facility for female offenders. It is situated south of Salem next to the Oregon State Penitentiary and the Oregon State Correctional Institution. It is a one-story, two-building facility with a functional capacity of 74 . When the questionnaire was administered there were 61 residents, which seems to be the characteristic population size.

The residents' rooms are located in two wings of the older building. Near the control room of the same building are two rooms where inmates congregate, both of which have television sets. Meals are served cafeterla style in a large dining room. Coffee is available at all times in the dining room, and women also congregate in this area.

The new building, opened in the spring of 1975, houses the library, classrooms, a multi-purpose room, the visiting room and the offices of the Superintendent and several staff members. The visiting room contains a number of tables with hard back chairs. There are toys and children's books avallable for the children visitors.

The facility is surrounded by a cyclone fence. The towers of the adjacent men's penitentiary provide observance capability. Within the grounds are a baseball diamond, a swing set for children and several picnic tables. This area borders on a well-traveled public road. In accordance with suggestions made in 1972 by an ad hoc committee 
of the Division of Corrections, several changes, designed to improve the atmosphere of the penitentiary, were instituted. A double lock system was installed in the dormitory rooms so that the women could have keys to their rooms to come and go as they pleased during the hours from 5:30 a.m. to $10: 00 \mathrm{p} . \mathrm{m}$. The inmates were allowed to wear their own clothes and decorate their rooms. Restrictions on going out onto the grounds were eliminated and outdoor visiting was allowed. Visiting was expanded to seven days a week, providing it did not interfere with the inmates' program.

\section{THE PROGRAM PLANN ING COMMITTEE AND REHABIIITATION}

\section{A penitentiary serves two functions: First, it protects society} from those found to be engaged in criminal activity. Secondly, it attempts to rehabilitate those serving time in order that they do not return to criminal activity after release. In 1965 OWCC was basically a custodial institution with no facilities for classes, therapy or recreation. In 1969 a part-time teacher was hired to teach in the cells. In 1972 the Intergrated Rehabilitation Services project was implemented on the philosophy that the women's rehabilitative needs could be most efficiently met by drawing upon the social service and educational facilities within the community rather than trying to provide everything within the prison.

The intergrated core team or Program Planning Committee as it came to be called, serves three functions. First, it helps each woman plan a rehabilitative program and coordinates services to fit her needs. The educational and job training resources, both inside and outside the prison, are drawn upon. If individual or group therapy is indicated and openings are available, the referral is made. Adjustment problems 
within the institution are discussed. The Program Planning Committee also makes maintenance assigments. Although construction of and participation in a rehabilitation program is not a requirement, all women must participate in maintenance assignments.

The second function of the Program Planning Committee is to receive reports on the social and program functioning of each waman from various staff members.

The third function is to review the woman's progress vis-a-vis the reports recelved, make suggestions to the women and prepare a report for the Parole Board. Although participation in program planning is not mandatory, if a woman fails to participate, the Program Planning Committee has little to report to the Parole Board.

The Program Planning Committee is made up of a Correction's Counselor, a Vocational Rehabilitation Specialist, a Children's Services Division Social Worker, and Superintendent of the prison. The former three are employees of their respective divisions within the Department of Human Resources and are on loan to work within the penitentiary.

\section{SERVICES AVAILABLE TO THE WOMEN}

There are two full-time teachers at OWCC. Those wamen who have not completed the high school equivalency, the GED, are encouraged to do so while in prison. Office skills such as typing, bookkeeping and shorthand are also taught. The recreation therapist provides classes in handicrafts, and a baseball team is being organized. There are two inmate clubs, the Spade Club and Imoge.

A psychiatrist is available for specifically requested evaluations. He also sees several women for on-going therapy. The part-time 
services of three psychologists are avallable. A psychological intake is done on each woman when she enters the institution. There are three weekly therapy groups available which women may elect to join.

Members of the Program Planning Committee are available should the women want to deal with personal problems outside a therapy situation (not all women belong to groups). The CSD Ilaison worker's duties include assisting in dealing with problems related to the inmates' children. He helps them establish and maintain contact with the caretaker of the children, assists them with legal problems, sometimes accompanying the inmate to court hearings, and communicates with the county Children's Services Division. He also helps them with transition planning.

In addition, educational facilities such as Chemeteka Community College are used to further the training of women whose crime and current behavior indicate they can handle minimum security. Eleven women are currently enrolled in this college.

\section{PAROLE}

The Parole Board consists of three members appointed by the Governor. The Parole Board meets once a month, usually with the inmate, to consider the report of the Program Planning Cormittee and to question the woman as to her progress and parole plans. An inmate does not go before the Parole Board until she has been at owCC for six months. The Board has three options: 1) to parole, 2) to deny parole or 3) to set-over. If parole is denied, the irmate must serve out her sentence. If she is setover, she comes before the Board again. There are no spelled out proced- 
ures concerning the responsibility of the Parole Board to explain to the Inmate the reason for set-over or denial of parole. Factors determining whether an inmate should be paroled include whether she is a physical threat to the community, whether she can be maintained and supervised in the community, the nature of her offense, the recommendations of the Program Planning Committee as to her reported behavior and progress in the penitentiary, how realistic her parole plan is, and the position of the community, especially the judge. Ninety percent of the women are released on parole.

\section{CONTACT WITH THE OUTSIDE}

The imate maintains contact with relatives and friends outside through phone calls, letters, visits and passes.

Phone calls must be made collect, but there are no restrictions on the number of calls made. The resident asks the control room operator to place the call and then takes the call from a phone booth near the control room. Once a week the CSD liaison worker allows the inmate mother a free "tie line" call to her children or their caretakers. There are no limitations on letters.

Each resident is allowed a visiting list of ten people, all of whom must pass a police check. Disqualifications are made on the basis of criminal record, known involvement in drugs or parole status. In cases where visiting interferes with an inmate's program, restrictions may be placed on particular visitors, time of visit, or number of visits.

Requests for passes, usvally 48 hours duration, are submitted to the Program Planning Committee and if approved there, are forwarded to 
the Superintendent for final approval. Passes are not allowed unt1l after the inmate has had her first Parole Board hearing (six months). Approval of a pass request depends on length of time served, sentence type and length and purpose of pass. A pass must generally be rehabllitative. The Inmate can be granted a pass only to see those on her visiting list. 


\section{CHAPTER IV}

\section{RESEARCH RESULTS}

\section{DESCRIPTION OF THE POPIIATION}

The mean age of the women interviewed was 28.4. Sixty-eight percent of the women were in their twenties, eighteen percent, in their thirties and eighteen percent in their forties. Fighteen percent of the women were married while thirty-eight percent had current relationships with a man, and forty-four percent were divorced and/or had no current relationship. In total, fifty-six percent of the respondents were, at the time, involved in relationships with men. Twenty-one percent of the women had never been married. It was determined that forty-four percent of the women had had one meaningful relationship with a man, thirty-two percent had two meaningful relationships and twenty-four percent had had three. The number of children of the respondents ranged from one to eight. Thirty-eight percent of the women have one child, forty-one percent have two or three children and twenty-one percent have four or more children. By combining the last two figures we find that sixty-two percent have two or more children.

The age of the children involved ranges from ten weeks to twentyseven years. Ninety-one percent of the women have at least one child in the age group zero to eleven years. Sixty-five percent of the women have at least one child in the age group zero to five years, the formative years. 
Breaking these groups down, it is found that twenty-six percent of the women have one or more children age zero to two years, and forty-seven percent have one or more children age three to five years. Thirty-eight percent have at least one latency aged child, in the age group six to eleven years. Twenty-four percent of the interviewees have at least one child twelve or over. This statistic allows one woman to fall into several categories if she has chlldren in more than one age group (see Table I).

In seventy-nine percent of the families the children in that family had the same father. In fifty-nine percent of the families there is a close father figure involved, not necessarily, however, the biological father.

TABLE I

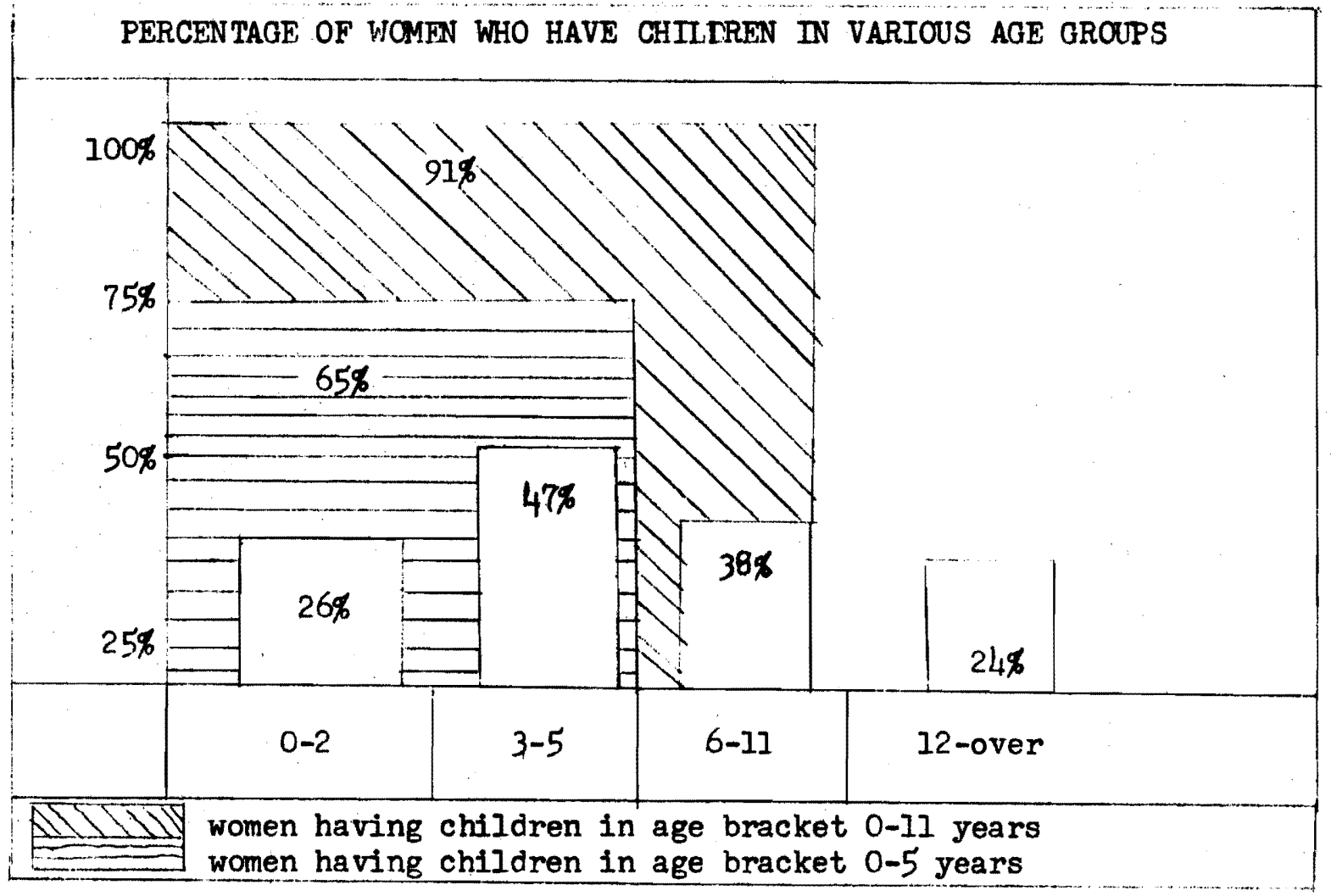


Seventy-four percent of the mothers were living with their children prior to incarceration. When asked if they had ever been away from their children for any length of time, sixty-eight percent indicated they had had only occasional brief separations (under four weeks), or had never been separated. The remainder, thirty-two percent, had previously experienced chronic separations, 1.e., foster care, loss of custody or separation due to prior incarceration.

To attain an indication of stability or lack of stability in the families of origin, the women were asked if they had ever been away from their mother (or mother and father) in their own childhood. Fifty-six percent of the respondents indicated that they had never experienced separation while nine percent had been separated for a period under one year and thirty-five percent had experienced chronic separations for over a year. of these, twenty-one percent had been in institutions. There was no relationship found between having had separation experience in the family of origin and having had separation experience from one's own children.*

In terms of our sample the crimes committed can be grouped into three categories: forty-nine percent of the respondents committed crimes against property, thirty-six percent comitted drug related crimes, and fifteen percent committed assaultive crimes.

Thirty-two percent of the respondents had been at OWCC for zero to three months, fifty percent had been there four to twelve months and eighteen percent had been there thirteen months or longer. The average length of stay at the time the questionnaire was administered was thirteen

$* x^{2}=.0251, p>05 d f=1$ 
months.

Many of these women had however been away from their children for longer, in that most had served time in a county jail before being sentenced at OWCC. Fifteen percent had been separated from their children zero to three months, forty-four percent had been separated from four to twelve months and forty-one percent had been separated thirteen months or longer.

When this group of mothers was surveyed for education and job background, it was found that fifty-six percent were high school graduates, while forty-one percent had completed from nine to eleven years of school and three percent had dropped out before the ninth grade. Fortytwo percent of the high school graduates had completed some college, while seventeen percent of them had had some vocational training, beyond high school.

Before their arrest, forty-one percent of the women were working while fifty-nine percent were not. Only fifteen percent had no work history. The jobs held were broken down into ten categories. In Table II can be seen the distribution of the ten types of work most frequently held by the respondents. The number of jobs does not corre- . spond to the number of cases because all the principal jobs for each inmate are listed, and thus one person may be represented more than once in these figures. 
TAEIE II

\begin{tabular}{|lc|}
\hline TYPES OF JOBS MOST WIDELY HELD BY RESPONDENTS \\
\hline & Frequency \\
1. Restaurant work & 15 \\
2. Office work & 13 \\
3. Factory work & 11 \\
4. Hospital work & 5 \\
5. Sales & 3 \\
6. Cashier & 3 \\
7. Domestic & 3 \\
8. Bank teller & 2 \\
9. Motel manager & 7 \\
10. Other (stripper, child care, \\
computer operator, air control, \\
landscaper, arts \& crafts \\
teacher
\end{tabular}

Eighty-six percent of the women with work histories stated they liked at least one of the jobs they had held and fifty-nine percent indicated they would return to one of the Job categories in which they had work experience. When asked if they earned enough money "to make it", sixty-two percent said they had. It was not determined if the women had additional sources of income to help support them and their children. The women were asked whether they were receiving training while incarcerated at OWCC. Fifty-nine percent of them were receiving some kind of training at OWCC while eighteen percent of the sample were attening Chemeteka Community College. Twenty-six percent reported they were not receiving any training. Of those who were receiving training at owCC, forty percent stated this consisted of classes including Value clarification and Charm. Sixty percent reported they were leaming secretarial and bookkeeping skills. Of those attending Chemeteka, thirty-three percent were taking liberal arts courses and sixty-six percent were enrolled in courses which were preparing them for jobs. 


\section{ATTITUDES AND FEELINGS REIATED TO SEPARATION FROM GHILEREN}

When asked to prioritize three areas of concern from a list of ten possible responses related to child, prison experience and outside concerns, the women responded in the following manner. First priority: Seventy-four percent were child related concerns, twenty percent were prison concerns and six percent were concerns relating to life outside the prison. Second priority: Seventy-six percent were child related concerns, twenty-four percent were outside concerns and there were no prison concerms listed as a second priority. Third priority: Twentysix percent were child concerns, twenty-six percent were outside concerns and forty-eight percent were prison concerns.

TABLE III

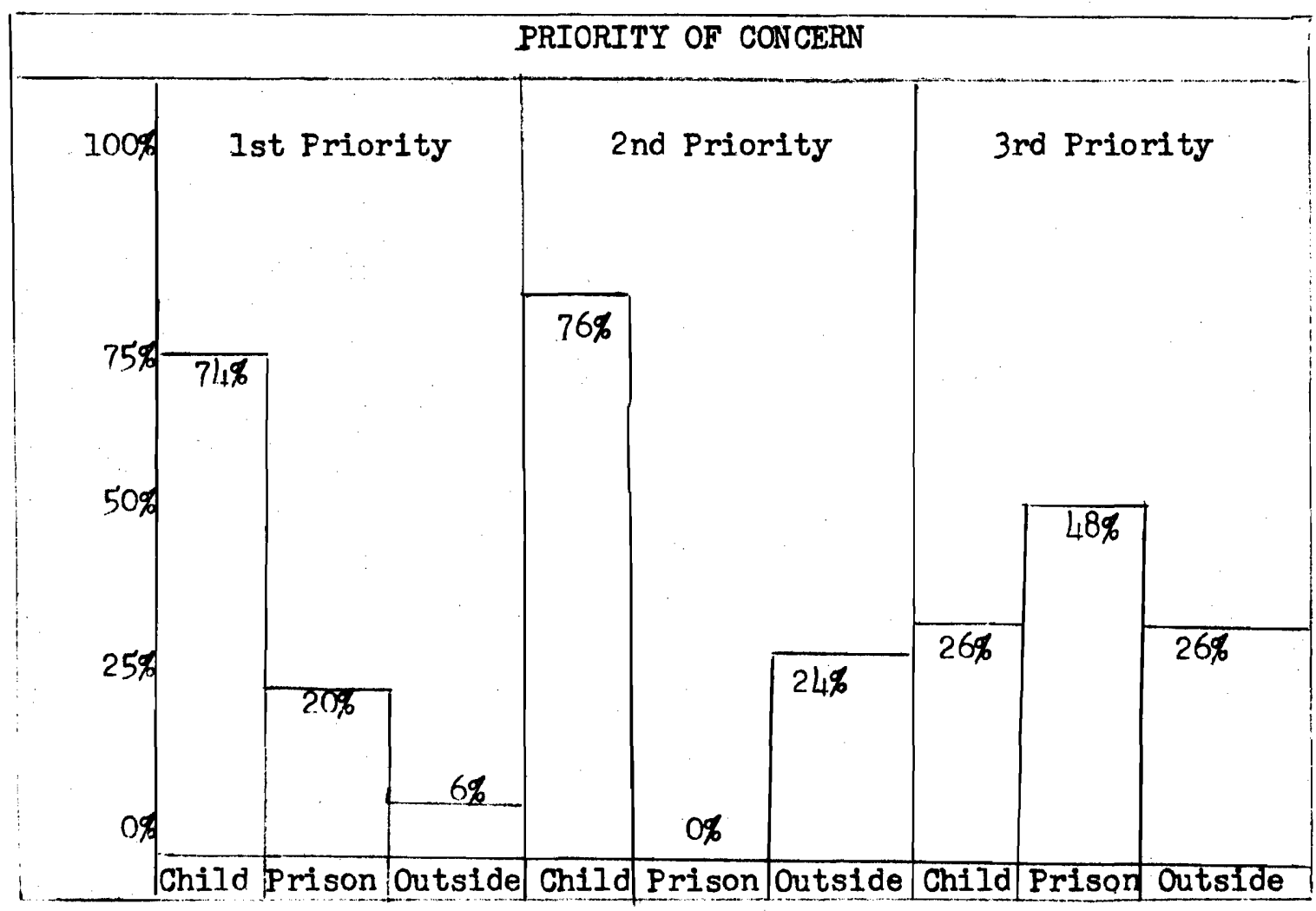




\section{QUESTIONS RELATED TO THE PLACEMENT OF CHIIIREN}

The children of the mothers surveyed fall into the following categories: Twenty percent of the women reported their children were in foster homes, sixty-two percent reported their children were with relatives and elghteen percent were in split placements (combination of relative and foster home care). Fifty-nine percent of the mothers responded that they had a choice in where their children were placed. Thirty-five percent did not have a choice and six percent had a choice in one placement, but not the other. Seventy percent of the mothers reported that they were satisfied with the placement, while trenty-one percent were not satisfied and nine percent were satisfied with one placement and not the other (split). The mothers were asked to specify their areas of satisfaction. Their responses fell into two categories; satisfaction with emotional needs and satisfaction with material needs. Sixty-two percent reported that they were satisfied that their child's emotional needs were being met whlle twenty-eight percent were not satisfied and ten percent fell into the split category. Eighty-one percent reported that they were satisfied that their child's material needs were being met while sixteen percent were not satisfied and three percent fell into the split category.

The mothers were asked to what degree they were involved with the care of their children. Forty-four percent responded that they did have some input into their child's care and fifty percent reported that they did not. Six percent had involvement with one child's care but not the other (split). Fourteen percent of the mothers chose to have no involvement with child's care. Of the mothers who reported they were involved, 
fifty-three percent stated they had low involvement and thirty-three percent had high involvement. To determine if there was a relationship between the child's placement (foster home, with family or split) and the degree of the mother's involvement, a chi square analysis was used.* A significant relationship between these two factors was found to exist. Mothers whose children were placed with non-family members were found to have less involvement with their child's care than mothers whose children were placed with relatives.

\section{THE GHILD'S AWARENESS OF THE MOTHER'S SITUATION}

The mothers of children over two years of age were asked if their children knew where they were. They were not asked if their children knew they were in prison. Fifty percent stated that their children knew where they were. Thirty-seven percent reported that their children did not know where they were and thirteen percent stated that due to split placements, some of the children knew and some did not. Twenty-seven percent of the respondents told the children themselves, while sixty-seven percent reported that someone else had told the children and six percent fell into the split category.

Thirty-eight percent of the mothers indicated that their children had been told the truth either by themselves or someone else. Forty-one percent reported their children were not told the truth either by themselves or by someone else, and twenty-one percent felt there were conflicting stories told by different people involved with their children.

* $x^{2}=6.07 p<.05 \mathrm{df}=1$ 
of the mothers whose children knew the truth about their situation ninety-one percent were satisfied with the explanation given to the children and nine percent were not satisfied. Of the mothers who reported that their children did not know the truth about their situation, thirtynine percent were satisfied with the explanation while fifty-one percent were not satisfied. Thirty-four percent of the mothers talk about the explanation with their children and sixty-six percent do not talk about it.

\section{MODES OF COMMUNICATION}

The inmate mothers communicate with their children through visits, tejephone calls and/or letters. Sixty-two percent of the mothers surveyed receive visits from their children. Fifty percent have telephone contact with their children and thirty-five percent communicate through letters. Fifteen percent have no communication at all with their children. These categories are not mutually exclusive.

TABLE IV

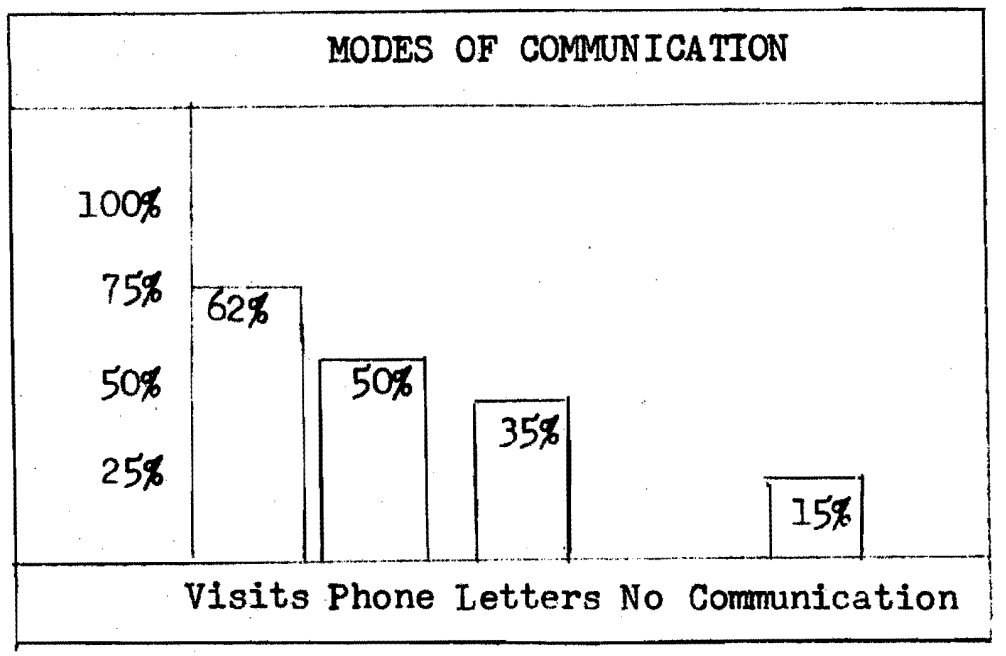




\section{VISITS}

Twenty-four percent of the mothers receive visits from their children once a week. Twenty-one percent report they visit once a month and twelve percent have visits once every three months. Another twelve percent receive visits once every four months or more and thirty-two percent receive no visits from their children. Twenty-six percent of the mothers were satisfied with the number of visits they recelve and seventy-four percent were not satisfied.

When asked what they perceived were the major barriers to more frequent visits they responded as follows: Thirty-two percent listed transportation and money as a barrier, twenty-six percent reported resistance from C.S.D. as a barrier, nine percent listed their relatives as a barrier, and six percent cited a combination of relative and C.S.D. resistance as a barrier. Twenty-four percent perceived no barriers to more frequent visits.

When the respondents were asked if there was anything they could do to increase the number of visits, thirty-three percent indicated they were actively attempting to deal with the problem and sixty-seven percent said they felt there was nothing they could do. The transportation and money barrier was not included in this question since it was felt that there was little a respondent could do in this area.

The inmate mothers were asked who decides when a visit will take place. Twenty percent indicated they decide while eighty percent reported that others declde when their children will visit. 


\section{OPINION ABOUT A DAY-CARE FACIIITY WITHIN THE PRISON}

The idea of having a day-care facility at the penitentiary for the children of the mothers was presented to the respondents. Seventy-nine percent stated they would approve of such an arrangement while six percent did not approve. Fifteen percent gave a qualified answer which generally indicated that they would be comfortable with the concept if the facility was closely supervised.

\section{EMOTIONS ASSOCIATED WITH SEPARATION FROM OHILIREN}

Each respondent was given a list of feelings and emotions. They were then asked to check the feelings they had experienced in relationship to their separation from their children. The following table is a computation of the feelings expressed by the mothers in the order of frequency and percentage with which they occurred.

TABLE V

FREQUENCY OF SPECIFIC EMOTIONS ELICITED THROUGH SEPARATION

$\begin{array}{llr}\text { 1. Worried } & 27-79 \% \\ \text { 2. Empty } & 20-59 \% \\ \text { 3. Helpless } & 20-59 \% \\ \text { 4. Guilty } & 17-50 \% \\ \text { 5. Afraid } & 13-38 \% \\ \text { 6. Angry } & 10-29 \% \\ \text { 7. Bitter } & 7-21 \% \\ \text { 8. Ashamed } & 6-18 \% \\ \text { 9. Resentful } & 6-18 \% \\ \text { 10. Thankful } & 5-15 \% \\ \text { 11. Numb } & 2-6 \% \\ \text { 12. Relieved } 1-3 \% \\ \text { 13. Paralyzed } 1-3 \%\end{array}$


The respondents were al so asked to give a referent for the selected feelings. The referents fell into the following categories: 1) self, 2) self-child, 3) child, 4) interpersonal, 5) prison related, 6) systems related. Table VI indicates the frequency of the referents. Table VII depicts the emotion and the frequency of the associated referent.

TABLE VI

\begin{tabular}{|c|c|c|}
\hline \multicolumn{3}{|c|}{ FREQUENCY OF REFERENTS } \\
\hline & Referent & Erequency \\
\hline $\begin{array}{l}1 . \\
2 . \\
3 . \\
4 . \\
5 .\end{array}$ & $\begin{array}{l}\text { Self } \\
\text { Self-child } \\
\text { Child } \\
\text { Interpersonal } \\
\text { Prison } \\
\text { Systems }\end{array}$ & $\begin{array}{r}15 \\
62 \\
17 \\
14 \\
17 \\
9\end{array}$ \\
\hline
\end{tabular}

TABLE VII

\begin{tabular}{|c|c|c|c|c|c|c|}
\hline \multicolumn{7}{|c|}{ EMOTIONS WITH FREQUENCY OF REFERENT } \\
\hline & Self & Self-Child & Child & $\begin{array}{l}\text { Inter- } \\
\text { personal }\end{array}$ & Prison & Systems \\
\hline 1. Angry & 2 & 2 & & 2 & 2 & 2 \\
\hline 2. BItter & I & 2 & & 1 & 3 & \\
\hline 3. Relieved & & & $\bar{I}$ & & & \\
\hline 4. Thankful & & & 5 & & & \\
\hline 5. Worried & & 13 & 9 & & 2 & 2 \\
\hline 6. Ashamed & 2 & 4 & & & & \\
\hline 7. Guilty & 2 & IL & & I & & \\
\hline 8. Paralyzed & & & & & I & \\
\hline 9. Empty & $\overline{2}$ & 13 & & $\overline{3}$ & 2 & \\
\hline 10. Numb & I & & & 1 & & \\
\hline - 11. Resentful & & & & $\overline{3}$ & $\bar{I}$ & 2 \\
\hline 12. Helnless & 2 & 11 & & 2 & 4 & $\bar{I}$ \\
\hline 13. Afraid & 3 & $\overline{3}$ & $\overline{2}$ & $\bar{I}$ & 2 & 2 \\
\hline
\end{tabular}


SEPARATION CONCERNS

The respondents were given a set of cards with a possible concern on each card. They were asked to remove the cards that did not apply, and to prioritize the remaining concerns. The concerns were classified as follows: 1) loss of attachment, 2) loss of chjld's respect due to incarceration, 3) caretaker encroachment on matemal bond, 4) self concerns after release, and 5) loss of custody of the child. Frequency, percentage and combined percentage are listed on Table VIII (page 30). The combined figure represents the percentage of respondents listing at least one of the concerns as pertinent to her.

The final section of the interview involved five open ended question sets related to the quality of visits, feelings associated with the visits, the effect of the separation on parenting ability, and the major problems resulting from the separation. Tables IX, $X$, $X I, X I I$ and XIII represent the women's perceptions in the above areas. 
TABIE VIII

\begin{tabular}{|c|c|c|c|}
\hline SEPARATION CONCERNS & Frequency & Percent & $\begin{array}{l}\text { Percent } \\
\text { listing at } \\
\text { least one } \\
\text { in group }\end{array}$ \\
\hline $\begin{array}{l}\text { I. Loss of Attachment } \\
\text { Will my child love me? } \\
\text { Will my child remember me? }\end{array}$ & $\begin{array}{l}13 \\
11 \\
\end{array}$ & $\begin{array}{l}38 \\
32 \\
\end{array}$ & 50 \\
\hline $\begin{array}{l}\text { II. Loss of Child's Respect Due to Imprisonment } \\
\text { Will my child be able to respect me after this? } \\
\text { Will I be able to talk about being in prison with my } \\
\text { child after I get out? }\end{array}$ & $\begin{array}{l}14 \\
13\end{array}$ & $\begin{array}{l}41 \\
32\end{array}$ & 53 \\
\hline $\begin{array}{l}\text { III. Caretaker Encroachment on Maternal Bond } \\
\text { Will my child think the person who is taking care of } \\
\text { him/her is a better mother than I am? } \\
\text { Will my child become more attached to the person who } \\
\text { is taking care of him/her than he/she is to me? } \\
\text { Will the person caring for my child turn my child } \\
\text { against me? }\end{array}$ & $\begin{array}{r}13 \\
13 \\
8\end{array}$ & $\begin{array}{l}32 \\
32 \\
24\end{array}$ & 64 \\
\hline $\begin{array}{l}\text { IV. Self Concerns after Release } \\
\text { Will I be able to work and support my child? } \\
\text { Will I feel like keeping house and taking care of } \\
\text { my children after this? }\end{array}$ & $\begin{array}{l}9 . \\
1\end{array}$ & 26 & \\
\hline $\begin{array}{l}\text { V. Ioss of Custody of Child } \\
\text { Will my child be taken away from me? }\end{array}$ & 9. & 26 & \\
\hline
\end{tabular}


TABLE IX

\begin{tabular}{|lcc|}
\hline \multicolumn{3}{|c|}{ QUAIITY OF VISIT -- ACTIVITY TAKING PLACE } \\
\hline & Frequency & Percentage \\
Interpersonal-enjoyable & 6 & 27 \\
Play & 6 & 27 \\
Nurturing & 2 & 9 \\
Interpersonal---diluted child contact & 2 & 9 \\
Weakened affectional bond & 2 & 9 \\
Anxiety--fear of loss of child & 2 & 9 \\
Activity and talk of future plans & 1 & 5 \\
Interpersonal---situational anxiety & $\frac{1}{22}$ total \\
\hline
\end{tabular}

TABLE X

\begin{tabular}{|lcc|}
\hline \multicolumn{3}{|c|}{$\begin{array}{c}\text { DIFFERENCES BETWEEN BEING AT HOME } \\
\text { WITH CHIID AND PRISON VISITS }\end{array}$} \\
\hline & Frequency & Percentage \\
I oss of mothering role---"doing for" & 4 & 22 \\
No time to murture mother-child bond & 4 & 22 \\
Inhibited setting & 3 & 17 \\
Exaggerated intensity of relationship & 3 & 17 \\
in visit setting & 2 & 10 \\
Not a part of child's growth process & 1 & 6 \\
Tension producing setting & 1 & 6 \\
No difference & 18 total \\
\end{tabular}

PABIE XI

\begin{tabular}{|lcc|}
\hline \multicolumn{2}{|c|}{ MOTHERS' FEEITNGS AFTER VISIT WITH CHILD } \\
\hline & Frequency & Percentage \\
Good & 4 & 18 \\
Down & & \\
Suppressed emotions & 2 & 9 \\
Anger & 8 & 36 \\
Depressed & 2 & 9 \\
Hard to separate & 4 & 18 \\
Alone and feeling empty & 1 & 5 \\
Confused & 1 & 5 \\
Uncontrollable emotion-expressed & $\frac{1}{22}$ total \\
\hline
\end{tabular}


TABLE XII

\section{MOTHERS' PERCEPTION OF THE EFFECT OF SEFARATION - FROM CHIIDREN ON PARENTING ABILITY}

Frequency Percentage

No problem

Increased appreciation of children

\begin{tabular}{rr}
15 & 47 \\
4 & 13 \\
4 & 13 \\
2 & 6 \\
2 & 6 \\
1 & 3 \\
1 & 3 \\
1 & 3 \\
1 & 3 \\
1 & 3 \\
\hline 32 total &
\end{tabular}

Difficulty in catching up with growth

old enough to get along

Anxiety but will overcome

Will be more strict in future

Will be too permissive from guilt

Will be tested

Anxiety

Don't know

$\overline{32}$ total

TABLE XIII

MOTHERS' PERCEPTION OF THE MAJOR FRORLEMS ARISING FRON SEPARATION

Frequency Percentage

Adjustment to changes in child because of differences in caretaker's values in child raising Fear of rejection

Child's security and welfare

Fersonal insecurity in mother role resulting from separation Physical separation (concrete) Fear of loss through system Psychological loss---grow apart Unfulfilled mother role None

$\begin{array}{lr}7 & 20 \\ 6 & 18 \\ 5 & 15 \\ 4 & 12 \\ 3 & 8 \\ 2 & 6 \\ 2 & 6 \\ 1 & 3 \\ \frac{4}{34} \text { total } & 12\end{array}$




\section{GHAPTER V}

\section{ANALISIS OF THE DATA}

In order to explore the feelings and attitudes of mothers in prison toward spearation from their children, this first objective was divided into three areas: 1) priority of mother role, 2) evidence of mother-child attachment and 3) indication of grief and loss. In supporting these topics, much of the same material from the structured interview is used repetitively.

The second objective, that of exploring the effects of imprisonment on the mother-child relationship, is obtained from the womens' statements regarding 1) communication patterns, 2) involvement in the care of their children while in placement and 3) satisfaction with the status of the latter two is sues.

In the final objective, system supports in maintaining the motherchild bond were reviewed, in light of the implications gleaned from exploring the feelings and attitudes of mothers in prison as well as their ability to maintain a satisfactory relationship with their children.

\section{THE PRIORITY OF THE MOTHER ROLE}

The biological route to motherhood is the same for all women, but the social route is not. Soclologically considered, motherhood is a position in a social structure. This position is tied to other roles in a set of interconnected groups of institutions. Each position is socially 
defined in terms of a set of expectations. The expectations that define a position in one population group differ from those that define the same position in another population group. Consequently, social context is an important element to consider when viewing the role of mother.

There is a complex interplay of social factors involved in motherhood and when the mother is separated from her child due to incarceration the complexity is heightened. A woman's mothering behavior has two resources: one is rooted in her physiology; and the other evolves as an expression of her personality which has developed under environmental influences. 26 The scope of this study does not allow for an extensive investigation of the past environmental influences, and therefore the research is limited to the woman's current functioning and her feelings about being separated from her children.

The separation from children is profoundly felt by the women at OWCC where sixty-four percent of the population are mothers. The impact of the separation from children is evident in a response to a question asking the women to prioritize the concerns they have experienced while in prison. Seventy-four percent of the mothers listed child concerns as their first priority and seventy-six percent of the mothers indicated child concerms as their second priority. (see Table III) These priorities concur with those reported by Ward and Kasselbaum in their study of a woman's prison. 27

Without arguing the issue of the determinants of social roles-whether they are factors in biological make-up or cultural or psychological---there are important implications for contemporary roles, needs and behavior arising from the division of labor among men and wamen. 28 
The women in this study seem to bring to prison with them identities and self perceptions which are based principally on familial roles such as wives, girlfriends, mothers, and their related roles. Qiallombardo noted the same role deliniation in her study of social roles in a prison for women. ${ }^{29}$ The women do not appear to be heavily invested in their occupation. The occupational history of the women surveyed indicated sporadic employment in jobs which require limited skills and formal training and they can be easily entered and left or worked part time. (see Table II)

Although it can be argued that the "home" roles that the respondents ascribe to are the basis for the occupational limitations they encounter, ${ }^{30}$ the vast majority of the women surveyed (eighty-six percent) liked their jobs and fifty-nine percent would go back to one of the jobs they have had. Several of the women who Indicated they would not go back to their job did so because their crime was involved with their job, (forgery, embezzlement etc.) but would return if they could. One respondent summed it up by saying, "Sure, I'd go back to the cannery. The money is good and the people who work there are friendly." The women appear to view their jobs as a source of financial maintenance and social outlet rather than as a source of social prestige or self esteem.

Although the women were not questioned on their feelings about family orientation per se, there are indications in the data that they are invested in a family unit as well as their role as a mother. Their relationship pattern reflects relatively stable interpersonal functioning with seventy-six percent of the respondents indicating they had had one or two significant relationships. Additionally, seventy-nine percent of 
the women stated that their children have the same biological father which would indicate that bearing children within an on-going relationship (marital or otherwise) is valued by the women.

Perhaps one of the most significant measures of the woman's investment in her role as mother is her presence in the home with the children. Prior to incarceration, seventy-four percent of the women were living with their children. Also, for sixty-eight percent of the women this separation was the first they had experienced. The data repeatedly points to the fact that for the inmate mother, role organization around the social1zation of the children is an important axis of self esteem and of interpersonal feedback and definition.

For most of the mothers at owCC visits from their children are very important. Yet, at the same time a visit is also a painful reminder of the effect the separation is having on their mother-child bond. The data again strongly supports the concept that for the majority of the women surveyed their self definition is confined largely to the area of mothering. When asked to describe the differences between being with their children in the home and visiting at the correctional Center, fifty-four percent of the women who received visits indicated dispossession of the mother role as the most significant difference. (No time to nurture the mother-child bond-twenty-two percent, loss of mother roleability to do for-twenty-two percent, and not being a part of the child's growth process-ten percent) (see Table $X$ )

The researchers are in agreement with Mimuchin, et al who state that it seems quite likely that conceptualizations about mother-child interactions based solely on individual interview data may be invalid; the 
actual facts of a dyadic system are more accessible when unfolded in real interaction. 31 Nevertheless the researchers feel the women's perceptions of themselves are crucial to understanding the dynamics of the separation experience.

Undoubtedly there are some readers who will find this polarization toward the traditional female role disheartening and a further indication of distorted structuring of Iife alternatives. 32 The women's movement has effectively brought these issues to the forefront. However it cannot be assumed that all women find the singular role of mother to be a unsatisfactory experience. As Zalba aptly states, it is quite possible that the role of mother is crucial to the inmate mother and her separation from her children and the concomitant major changes in her role strikes directly at her essential personal identity and self-image as a woman. 33 The researchers feel the polarization toward the traditional female role is due to a multiplicity of determinants and fallure to examine the dynamics of their unique experience would be ignoring the social context within which the women function.

For whatever reason, and there appear to be many, the majority of the women who participated in this study gave mumerous indications that their sense of self depends on fulfilling the mother role. To summarize, the priority of the mother role is substantiated in the following areas: 1) overriding concern for their child's welfare as exemplified in the prioritization of concerns, 2) lack of investment in occupational status, 3) stable relationship patterns and bearing children within an on-going relationship, 4) physical presence in the home and low percentage of previous long term separations from children and 5) focused awareness on 
the dispossession of the mother role. It should be made clear at this point that the researchers cannot fully assess the formation of this priority on the basis of one interview. Consequently, it cannot be determined whether the investment in the mother role is healthy or unhealthy, adaptive or maladaptive, real or unreal.

\section{EVIDENCE OF MOTHER-CHILD ATTACHMENT}

Before one can consider separation as having an impact on an individual, there must be some attachment to an object, the quality and depth of which partially determine the significance of the experience. Though our questionnalre did not attempt to ascertain the quality of the relationship between mothers and their children, there are several ind1cators that reflect the basic assumption of the existence of an emotional bond or attachment.

There is good evidence that most children develop strong attachments to their parents. 34 Though there is great individual variation in the strength and distribution of attachments, normal development of a child requires attachment behavior as a fundamental characteristic of the mother-child relationship. In the United States, children under the age of five years and in the custody of their biological parents, are generally in the care of their mother. This presumption is utilized in guiding courts in determining the best interests of the child, 35 and is culturally reinforced through sex roles. Of the thirty-four mothers interviewed twenty-two had children under the age of five years, seventeen of whom had never been separated from their children before. In addition to children in the critical first five years, those who are eleven years and 
younger are also dependent on their parents for the development of their identity and sex roles. Thirty-one of the mothers had children at this level of development. Combining the above data, it can be said that ninety-one percent of the mothers interviewed have dependent children in need of consistent parent bonds (see Table I).

As well as reflecting her investment in the mother role, one of the strongest indicators that the majority of mothers had an on-going relationship with their children was the fact that seventy-four percent of them were living together before the arrest. The degree of crisis involved in the enforced separation is hinged partly on past experiences of separation. Sixty-eight percent of the mothers had never been away from their children. Those who had previously been detached from their children or were not living with them before imprisonment, gave the main reason as being that of previous incarceration.

Additional evidence of mother-child attachment is noted in the fact that seventy-six percent of the mothers indicated the problem of being away from their children or worrying about how the children were doing as a top concern while in prison. All of the mothers expressed the latter concerns as first or second choice when stating what worried them most while in prison. Worry as one possible sequence of a caring relationship, particularly by a parent for the child, was communicated by eighty percent of the mothers. Prevailing themes in discussing their concerns include the child's well being and happiness, as well as the effect of being separated on the relationship. of the thirty-four mothers, twenty-six expressed an overriding major problem resulting from their incarceration would be the effect on the bond with their children. 
To summarize, there are three significant areas that indicate evidence of mother-child bonds by the women interviewed in this study: 1) the predominance of children involved that are under the age of eleven years and in need of parental care, 2) the lack of previous separation experience except for past incarceration, and 3) the overwhelming repetition of concern and worry by the mothers for their children.

\section{INDICATIONS OF GRIEF AND LOSS}

It has been shown that for the women in this study the mother role provides a source of identity which they do not attain in their other social roles. The data also indicates that an attachment, a bond, does exist for the majority of the mothers, even though this study provides no definitive measure of the quality of the bond.

Therefore the loss due to separation involves loss of the mother role and loss of the children themselves. Examination of the content of the grief response experienced through enforced separation is not, however, clear and simple. Unlike studies dealing with the adult grief reaction to death by Lindemann or Kuibler-Ross or that done by Bowlby on children who are separated from their parents, the grief reaction of mothers separated from their children through incarceration is compounded by the multiplicity of the loss experienced. These women experfience loss of liberty and social acceptance, loss of material comfort, loss of heterosexual relationships, loss of personal autonomy and loss of security---those losses sustained through imprisonment, 36 as well as those endured as a mother. The grief of the loss of the child is therefore altered and shaped by the context of deprivation within which it occurs. 
Despite the complexity of this loss experience, the literature on loss and grief through death and separation can be used as a framework from which to depart. Bowlby's second stage of separation, that of despair can be characterized by a wide spectrum of emotions and responses as described by numberous authors. Those most of ten reported in normal grief are emptiness, sadness, helplessness, loneliness, anger, guilt, depressive symptoms, somatic symptoms and a preoccupation with thoughts of the lost one.

The grief content of the inmate mothers of this study seem to correspond to the grief content found as responses to other losses such as death. Significant information relating to grief content was elicited in the interview process, particularly in the feeling-referent section (see Tables V, VI,VII) and in the section dealing with concerns experienced by mothers who have been separated from their children due to incarceration (see Table VIII). The feelings most often mentioned in the former section were emptiness, helplessness, guilt, anger, fear and worry.

The reported feelings cannot be assumed, however, to represent the actual dynamics of grief in these mothers. The interview schedule could not ascertain where and to what extent defenses against feelings such as repression, denial, displacement and projection, occurred nor to what extent answers reflected the interviewees desire to give responses desired by the interviewers. Nevertheless, the data can be viewed as subjective reportage, an exploratory attempt to gain an understanding of the grief content.

In the following discussion the grief content of the respondents will be explored and the possible dynamics of the reaction presented. 
Emptiness was a feeling experlenced by fifty-nine percent of the mothers interviewed. The referent elicited was overwhelmingly selfchild oriented, sixty-five percent. Responses such as "part of me is gone", "they were my I1fe", and "I miss not doing for them" prevailed, reflecting both the loss of the children and the loss of the maternal role. Predominant in the responses was a sense of void as a result of an integral part of their lives having been taken away.

Mandelbaum, in his discussion on the significance of child placement to parents, notes that after placement parents fear the energy they have put into the struggle of parenting will be gone and "the vacuum created in their lives because of the child's absence will cause then to lose momentum, their reason for struggle, their reason for existence." 37

The frustration over having lost the total role but still trying to maintain the bond is brought out by the high percentage response, fifty-nine percent, to the emotion, helplessness. Themes mentioned here include helplessness at not being able to contimue the mothering of the child, being able to meet the child's needs wille in prison. The poignancy of the frustration is illustrated by statements similar to, "I am a mother but I have to depend on others to mother my ch1ld." They wanted to be doing things for their child themselves, wanted to be a part of their child's growth process, and wanted to make sure the child was taken care of in the way they would if they were there. Many of the self-child referents in response to the emotion, worry, reflected similar foelings. Another reflection of such feelings was attained when the mothers whose children visited were asked to talk about the differences between being with their child at home and prison visits. Fifty-four percent of 
the responses were reflections of the dispossession of the mother role ( see Table X).

Feelings of helplessness and dependency experienced in relationship to the maternal role are compounded by the helplessness incurred as a result of the loss of autonomy associated with institutionalization. Sykes states that "the frustration of the prisoner's ability to make choices and the frequent refusals to provide an explanation for the regulations and cammands descending from the bureaucratic staff involve a profound threat to the prisoner's self image because they reduce the prisoner to the weak, helpless, dependent status of childhood." 38 This deprivation of autonomy represents a serious threat to the prisoner's self image. Several inmates reflected on the anxiety they felt about adjusting to such everyday responsibilities as cooking after they were released. Burkhart's extensive in-depth interviews repeatedly emphasize the pain experienced through forced dependency. 39 The feelings of helplessness, sustained through separation, therefore are compounded and extended through institutionalization. This indicates that resolution of these feelings would be more camplex within the prison setting.

Although depression was not directly explored, it did come out as a response to feelings experienced after the inmates received visits from their children. Thirty-six of the women who received visits reported that they felt depressed after the visit, while eighteen percent felt alone and empty. The majority of the women, whether they felt angry, depressed, confused, or empty stated that they took these feelings to their rooms to deal with in privacy. Few felt they could share their emotions with other imates. Only eighteen percent of the women reported 
they felt good after visits. (see Table XI) Visits, although desired, served to remind them of the pain of loss. Psycho-dynamically, depression is an emotional state in which anger is not allowed expression, but rather is directed inwards towards the self. It is an expression of loss and helplessness in the face of that loss. 40 Phyllis Chesler notes that our society tends to restrict females to depression rather than agression as a response to loss. 41

Anger is an emotion that is difficult to accept both by the angry person and by those in his environment. Yet anger as a response to separation and loss has been found to be integral part of the grief process. 42 A total of fifty percent of the women in this study expressed either anger or bitterness in relationship to the separation from their child. The referents of the anger were widely dispersed botween interpersonal (largely husband or father figure), prison, systems, self-child or self. Themes expressed in the referents were often related to disappointment in the lack of support of the mother-child relationship by those from whom support was expected.

Anger needs a tangible recipient. The bereaved finds it difficult to be angry at something as intangible as loss. The woman may perceive the cause of the loss to originate in herself or to be a result of the unfairness of the system. Or, she may seem to accept the separation and be angry at the lack of support received. It is important to recognize that no matter what object the anger is directed at, and no matter how valid the anger at that object is, a large portion of the anger is nevertheless the result of the loss and the pain attached to it. Expression of the anger is difficult within an institution where 
maintenance of order is essential. It is especially difficult within the prison setting where anger, little understood by the angry person himself and often greatly displaced, can be misinterpreted by inmates as well as staff and can easily reflect on one's adjustment and result in an unfavorable parole report. Inmates are well aware of this and therefore expend considerable energy in suppression of anger. Yet working through the anger exploring its causes and dissipating it through expression is essential to processing the grief.

Both the literature on grieving and that on filial deprivation stress guilt as a strong component of the grieving response. 43,44 The bereaved reproaches himself for not having done better in the past, and for the loss itself. This emotion was expressed by fifty percent of the inmate mothers. The majority of the referents, eighty-two percent, were self-child oriented. The guilt was not reported as relating to the commission of a crime but rather to depriving their children of their care through being imprisoned. They expressed guilt and pain that their children were suffering for what they had done. Several were acutely aware that their imprisonment might scar their child's emotional development.

Guilt at not being with the child is complicated by the nature of the separation. No other separation provokes the degree of social stigma as does imprisonment. Forty-one percent of the respondents were concerned about whether their child "would respect them after this", and thirtyeight percent were concerned about whether they would be able to "talk about being in prison with my child when I get out." Combining these two statistics, it is found that fifty-three percent of the women mentioned either one or the other of these concerns as pertinent to them. (see 
Table VIII) The data shows, therefore, that for many of the inmate mothers the combination of guilt at not being with their child and the loss of face and respect in relation to their child by having been imprisoned represents a very difficult issue.

This point is further emphasized by the fact that in sixty-two percent of the families the child was either told a false story about where the mother was or was told conflicting stories. While most mothers whose children were told (or who told their children) the truth were satisfied with the explanation given (ninety-one percent), forty-one percent of those who told false stories were not, and thirty-nine percent were. A chi square value was obtained on the relationship between 1) presence of concern about whether the child would respect the mother and whether the mother would be able to talk about being in prison with the child afterwards and 2) whether the mother had told her child the truth about where she was. It was found that a statistical relationship does exist.* Although many of the mothers who did not tell the truth about imprisonment gave the impression they felt it was more important to conceal the reality from their children, the relationship would suggest that telling the truth reduces concern and not telling the truth results in continuance of such concern. Considering the reciprocity of the motherchild relationship, it would seem that a lowering of the apprehension about how the child will recive her would result in the mother being better able to re-establish the bond after release. Guilt, therefore, produces fear of loss of respect due to the stigma attached to imprisonment. Separation from their children also $* x^{2}=6.76 \mathrm{p}<.05 \mathrm{df}=1$ 
represents a threat to the mother-child bond. Not only do the mothers fear that their child will stop loving them or forget them, but also that they will become more attached to the present caretakers. This is illustrated by the fact that fifty-elght percent of the mothers with children under twelve years cited either "Will my child love me" or "Will my child remember me" as a concern while sixty-five percent cited concerns related to the pre-emption of the mother-role by the caretaker as concerns (see Table VIII). In the feeling referent section many of the women expressed fear and worry about their reunion, including fears about how their child would receive them and what harmful effects the separation might incur. Some mothers, twenty-six percent, were concerned about legal custody.

The explanation of these fears, be they reality based or otherwise, is complex. Certainly fear of loss of love and attachment is based in part on rcality. Goldstein, et. al., stress the importance of time to small children; that, although adults can maintain the memory of a loved one for long periods of time, young children cannot. 45 some of the mothers interviewed seemed to be aware of this while others did not. Tespite the fact that few mothers lose custody solely due to imprisonment, there could be a reality basis for this concern among some mothers.

It is likely, however, that these fears are, in part, the result of guilt. It must be very difficult for the mother whose identity is basfd on mothering more than on any other role in her life to handle the guilt of having deserted her child through imprisoment. Expiation of the guilt could take the form of fear of rejection. The mother views herself as "bad" for having caused the separation and therefore feels her 
child will stop loving her. In extreme cases detachment from the child might result as the mother rejects the child before he has a chance to reject her.

Fear of the caretaker replacing the mother could occur in like manner. Mancelbaum found in his work with parents of children who had been placed that they who are "bad" parents are afraid they will be replaced by "good" parents. He notes, also, that staff, fantasizing themselves as rescuers of the child, often reinforce the guilt through overidentification with the child, resulting in the parents sinking deeper into pessimism about their own parental capabilities. Similarly the caretakers may fantasize rescuing the child from the "criminal mother". In this study there were several cases in which mothers reported hostility on the part of relatives or C.S.I. to bring their children to visit. There is yet another component of the grief response. Prison employees have noticed that the inmate mothers seem to exaggerate or idealize the maternal role while incarcerated. While this study shows that the interviewees did place a high degree of importance to the maternal role, it did not ascertain to what extent this response was exaggerated beyond that which existed before incarceration.

The literature on the grief response would suggest that such an idealization does occur. Iindemann notes that the bereaved is often preoccupied with thought of the lost one. 46 This phenonomen can be oxplained as an attempt to "undo" the loss, a loss for which the mother feels acutely responsible. It might also be hypothesized that idealization of the mother role results from loss of autonomy within the prison setting and as a mother, in that while in the "concrete womb" mothers 
reach out in memory to the time when they were autonomous and others depended on them. Contimance of such idealization distorts reality based plaming. She may not be prepared for the difficulty of the reunion. Although the response of incarcerated mothers to the loss of their children is complex, it closely resembles the grief occurring as a response to other forms of loss. Emptiness, due to the loss of chilldren as well as role occurs. Helplessness is felt as a result of the frustration at trying to maintain the relationship while in prison. Anger at the loss occurs but is displaced and added to anger at others. The unacceptability of expression of anger in the prison setting results in its energy-draining suppression. The guilt felt for being the cause of the separation leads to fear of rejection by the child and apprehension that the child may grow more attached to the caretaker as a result of the separation. The stigma attached to imprisonment makes it difficult for the mother to be straight-forward about the reason for the separation thus compounding the parent-child gap through lack of honesty in communication. Idealization of the relationship further impedes reality based planning.

\section{EFTECTS OF TMPRISONMENT ON THE MOTHER-GHIID BOND}

In that there has been strong indication that the investment in a mother's role is central to the deprivation experienced by a woman in prison, the ability to maintain the bond with her child is critical. As noted in describing the range of loss and grief responses, one can say that physical separation does not put an end to the emotional and psychological ties that bind a family together. The response of a woman in 
maintaining these ties with her child varies according to a number of factors, including her mothering investment, the quality and interdependence of the relationship, the amount of stress she is undergoing, and the age and development of the child. The manner in which the bond is supported is also dependent on the prison and placement constraints. Commanication with the separated child could be considered a primary means of retaining an affectional bond. Though half of the mothers interviewed indicated use of the telephone as a means of making contact with their families, exploration was mainly centered on the use of visits. Twenty-two of the thirty-four mothers had visits with their children at the prison. The quality of these interactions in facilitating the motherchild bond is unknown. However, in the open-ended questions pertaining to what the visits were Iike, fifteen of the twenty-two mothers expressed a positive enjoyable exchange, including play, nurturing, discussing what they did while apart, and making future plans. The seven who had more difficulty in the visit, expressed anxiety from fear of loss, inhibition from lack of privacy and weakened attachment by the child due to the amount of time involved in the separation. (see Table IX)

As stated in the theoretical framework, separation constitutes object loss, and that loss is resolved through a grief process. One study has noted that there is a relationship between frequent contact between parent and child following separation, and the duration of grief work as well as the quality of affect and behavior of the child. 47 Considering the reciprocity of the relationship, this would imply that there may be shorter time for grief resolution, as well as better adaptation to enforced separation by mothers who receive numerous visits than by 
those mothers who have minimal or no contact with their children. Approximately a third of the mothers who receive visits, have weekly contacts with their children. Another third receive monthly visits, while the remaining third have more than a month lapse between contacts. Only six, or twentyseven percent of the twenty-two mothers were satisfied with the number of visits, five of whom received weekly contacts. Those who were satisfied with the frequency with which they were seeing their children expressed no barriers in obtaining the visits and were involved in deciding when they took place.

Over one third or twelve, of the mothers interviewed had received no visits from their children. Six of these mothers had children four years and younger. From studies on the effects of separation, there would be no question as to the impact of time and broken continuity of the maternal bond on the adjustment of these children at such a vulnerable age. The effects of separation on these mothers vary according to individual circumstances. All of these six mothers were dissatisfied with receiving no visits from their children and infants. All expressed feelings of loss through a variety of emotions. However, anger and bitterness were particularly noted by mothers whose young children were in foster placement, while relief and acceptance were more prevalent among those mothers depending on relatives for visits and care of their children. When asked how all the mothers felt about Day Care at the Correctional Center, more than three fourths of the population expressed an unqualified destre for such a program. This reflects a general concerm for maintaining the bond with young children at a critical developmental stage. 
The remaining six mothers who received no visits, had children ranging from five to twelve years of age. Although not as critical a stage as the first four years of life, this developmental phase could include problems in identity and sex role conflicts, as well as with excessive anxiety related to the mother's absence. The most common mantfestation of problems would arise in school learning difficulties and peer relationships. Two the mothers of these latency aged children chose not to have visits, though expressed general worry about their children's welfare. One felt that her child was "well adjusted, and there is no reason to bring him to an abnormal environment to mess up his head." The other four mothers of elementary school aged children experienced a broader range of grief and emotions in the separation and were not satisfied with the lack of contact. Anger and bitterness were again expressed because of lack of communication from foster parents and Children Services' Workers, and a couple of the mothers reflected detachment and depression in accepting resistance by the caretakers, as well as threats of losing custody. The latter two mothers had been incarcerated for over a year without contact with their children, and appeared resigned to losing them. Besides contact and communication, invol vement in the decision making and care of one's child can result in improved functioning for both mother and child. Enhancing the mother's self esteem as an individual as well as her parenting ability, has been recorded in the literature. Reciprocal effects on the child include strong self concept, ability to establish peer relationships as well as stronger ties to the natural parent. 48 Half of the total population interviewed stated that they were given no choice nor any part in how their children were being cared for. 
This would include both those chldren placed in foster homes as well as with relatives. Only two of all the mothers stated that they did not want to be involved, both of them relying on their confidence in the abilities of the relatives with whom the children were placed. All those who were not satisfied with their children's placements (twenty-one percent) were also not participating in their care nor satisfied with the emotional well being of their children.

To summarize, the main effects of imprisonment on the motherchild bond was explored through the woman's perception of the visits and her involvement in her child's care. There were three significant issues that resulted from this study: 1) Frequency of visits was related to satisfaction with communication and indication of lack of barriers. This factor may also have implications on the duration of grief work as well as adjustment to enforced separation by both mother and child. 2) of those who received no visits, a more severe impact was expressed by mothers who had children four years and younger. This may reflect the reciprocity of the relationship in that the first years of a child's Iife are especially vulnerable and dependent on the continuity of a significant adult relationship. 3) Parent involvement appears to be related to satisfaction in placement of their child. This could have implications with the mother's self esteem and parenting ability as well as the chld's adjustment.

\section{REVIEW OF PRISCN SUPPORTS IN MAINTAINING THE MOTHER-GHIID BOND}

In exploring the mother role and separation experiences of women from their children while incarcerated, one becomes aware of the range of individual differences in responses. However, there is an overriding and 
common theme expressing painfulness and loss in this area. In that the conditions of imprisomment deprive one of freedom and autonomy, the female inmate is dependant to a large extent on the system for maintaining communication with her family and responding to her needs.

The institutional aspects of the prison presents problems in allowing a woman to freely express her grief and emotions in coping with her deprivation. Enforced living in close proximity with women of different backgrounds, values and needs, develops a tendency to suspicion and distrust that can evoke acute insecurity and anxiety. "You have to watch who you make friends with, who you talk to" was expressed by a woman who had been confined for a year, and had done lots of "hard time". The value of "easy time" is that of focusing one's energies and thoughts to the present, and mainly to events within the prison while serving a sentence. Management of feeling is required by the woman if she is to be successful. Those who attempt to maintain strong psychological ties with the1r family and friends in the outside world place a strain on their adjustment to prison life, evoking frustration and upset that can result in "hard time", or lack of meritorious "good time". "The psychological transistion of self from civil society to the prison world may be considered complete when the individual reacts neutrally to events in the outside world, even when these events concern crucial matters pertaining to family members." 19 Comments made by the women interviewed reflect pressure to suspend one's emotional involvement, except for inmate relationships, in order to complete the prison sentence successfully. "This place turns warm-hearted people into cold people." "This place makes one not care." "Al] my feeling is walking out the door with my child after 
visit." "I don't let myself feel." "I try not to think about my child." "It is best that one go to her room to adjust and not let things bother her."

The psychological services that are available to a woman in making her adjustment to the Correctional Center are indicated upon entry when each individual is evaluated by a psychologist. Three therapy groups are offered to voluntary members or those who have been recommended to participate by the Program Planning Committee. The general content of these weekly gatherings is to provide an arena for self understanding, communicating interma] problems of stress and assisting toward an adaptation to the prison lifestyle. A psychiatrist is available for individual. therary. The women may choose to be advised by any one of the three members of the Program Planning Committee, though a social worker, emplojed full time by the Children's Services Division, is mainly responsible for problems with placement of children, adoption, custody and transition planning back to the family. There appears to be no specific formm where a woman can express her family concerns and better vnderstand her matermal role, except through initiating contact with one of these three staff members.

One of the more significant aspects of an environment conducive to expressing one's feelings and needs, is that of a trusting relationship. There appears to be no support for confidentiality at the Correctional Center. All information and emotional conflicts in dealing with separation from one's family, as well as getting along with the women inside, becomes a part of the institution's perception of a woman's tota] adjustment to the correctional environment, and is subject to 
rriview by the Program planning Commstee. This lack of confidentiality wovel undoubtedy reinforce the wariness and caution in expressing one's feelings and prevent movement toward healthy resolution.

In communicating with their children, the main barriers to obtaining frequency of visits was indicated by the women as transportation, and Children's Services Division and Foster Parent resistance. The dependency of these women on the institution is reflected by sixty-seven percent who felt they couldn't do anything about it. Several stated that they had expressed frustration with the situation, but did not feel any change was forthcoming.

Obtajning passes to visit her family is subject to vague criteria by the Program Flanning Committee which is not always made clear to an inmate. She is required to be in the prison for six months, or have an initial interview by the Parole Board, before temporary leaves can be considered. As a cautionary measure, this would allow time for assessment of the individual and determine the threat to the community. However, it also encourages detachment of involvement in order to do "easy time" when returned to the prison.

Another dissatisfying aspect of communicating with their children was expressed by some mothers in the lack of comfort and privacy when visiting at the Correction Center. Since a majority of the year in Oregon is rainy and cold, visiting takes place mostly indoors. "There is no space or privacy to express one's mothering and say what you really feel." "One has to keep the children quiet and controlled." "There is not much opportunity for spontaneity, wrestling and romping." "I feel guilty about trying to discipline my children when everyone is around." Con- 
sidering the stress involved in attempting to maintain a close relationship with one's child while in prison, the painful visits can be compounded by the institutional constraints.

In making plans for reentry into society, a woman with children has a complex task. One of the most troubling aspects in planning by a mother in prison is described by Galtung as "institutional uncertainty". Not knowing how long she will serve time in confinement prevents any realistic goal setting. "The indeterminate sentencing law's of the state comrined with the philosophy of individual treatment results in what is perceived by both staff and inmates to be inconsistent action by important institutional committees and by the Farcle Board." 51 As discussed earlier, (peges 14 and 15) several factors are considered by the Parole Board in attempting to treat the woman individually. Because of the subjectivity and the inconsistency involved in this procedure, a woman's dependence and lack of security are even more exaggerated, again presenting barriers to realistic planning for her children.

In summary, the Oregon Women's Correctional Center presents institutional problems in assisting a woman to maintain contact with her child. In order to do "easy time" and adjust to the environment, emotional involvement in family concerns creates strain. There is no specific confidential forum to express the grief and feelings related to separation from a woman's children. Passes are not given until after an acculturation period of six months, which tends to encourage detachment from her former life style. Problems inherent in institutional visiting were noted as well as system barriers in obtaining the visits. The parole decisionmaking in the Criminal Justice System presents much vague and unclear cri- 
teria in setting sentences and individual treatment, deterring the possibility for making realistic plans for the time when life on the outside of prison can be resumed.

\section{CONCLUSIONS}

The purpose of this study was to examine the feelings of imprisoned mothers regarding the separation from their children, in view of the fact that these mothers will eventually reunite with their children. Consideration of the meaning of the dismuption of the mother-child relationship to the motherderivesits importance from the fact that the subjective experience of the mother determines, in part, the nature of the reunion. Although the study was exploratory and verification of the results through further research is needed, significant conclusions can nevertheless be draw.

It was found that the maternal role represents the axis of self esteem and meaningfulness of life for this group of women. At this point in their lives investment in other social roles such as occupation does not reach the level of priority as does the investment in the role as mother. Therefore, imprisonment and consequent separation results in a profound threat to the self esteem.

The study also shows that for the majority of the women an attachment to their child did exist prior to incarceration. Both the data and the depth of emotional involvement in the interview itself support the conclusion that the bond is still present, even though many must struggle to maintain it despite the barrier of physical separation.

As previously stated, the researchers do not purport to have a 
measurement of bond or committment prior to incarceration. It is possible that incarceration and separation have heightened the sense of committment. Such a differentiation of factors contributing to the sense of emotional bond would be difficult to ascertain in one interview. For whatever reason, the mothers interviewed in this study at this time perceive their role as mothers as primary to their sense of identity and view their imprisonment as a deprivation to their children.

The psychological impact of the seraration was found to closely resemble other forms of loss such as those experienced through death, divorce and separation for children. The grief response of the women studied was characterized by emptiness, helplessness, anger and bitterness, guilt, fears of loss of attachment and of rejection. The difficulty of talking with the child about the reasons for the separation indicates the degree to which imprisonment has already affected communication patterns. Although many mothers do not foresee difficulty in reunion, the researchers feel that this may be unrealistic considering the intensity and complexity of emotion expressed. It is felt that without adequate "working through" of the grief associated with the separation, repercussions in the mother-child relationship will occur.

Maintenance of the mother-child bond while incarcerated plays a crucial part in reducing the effects of separation. It was found that while frequent visiting was related to satisfaction in communication, absence of visits created a more severe emotional response especially among mothers of preschool aged children. Involvement in the care of the child also increased satisfaction in placement. In the opinion of the researchers, increased bond-maintenance supports would further lessen 
the detrimental effects of imprisonment on the mother-child relationship. It has been shown that the loss with its concomitant stressful emotions is both experienced within and complicated by a setting which is not conducive to its processing. Psychological adjustment to prison Iife requires that one smother his emotions and present a smooth surface. Such a front is valued by both staff and fellow inmates in that inadequate control of emotion might result in "hard time" or an unfavorable parole report. Furthermore, prison itself induces forced dependency which is antithetical to the requirements of the mother role. 


\section{CHAPTER VI}

\section{RECOMMENDATIONS}

According to the Uniform Crime Report, (1974) for all property crimes in the United States between 1960 and 1973, the rate of female arrests increased three hundred-fifteen percent. During that same period violent crimes committed by women increased one hundred-thirtyfour percent. 52 There are mumerous theories that attempt to explain the dramatic increase in female crimes. While female criminality has not been specifically addressed in this study, the researchers are most closely ali gned with those theorlsts who place an emphasis on institutional features as an explanation for crime. These theorists Iso maintain that there is a need for structural rather than indivicual charge in order to prevent and control crime. 53

If, in fact, basic structural changes are needed to alleviate the inequality and oppression that exists in our society it seems fairly certain that the changes will not occur without a great deal of enlightenmont and eventual reordering of priorities. It also seems certain that in the interim thousands of women will continue to be processed through the crimina] justice system. The following recommendations are designed to serve as suggestions for prison administrators currently charged with the task of "resocializing" the inmate-mother. They are by no means a support for the status quo; the researchers stand firm in their belief that for any real change to take place it must originate outside the 
prison.

1. Recognition by the staff of the priority of the mother role. The Inmate-mother's own rehabilitation and adjustment are sharply affected by her maternal role and her relationship relative to her children. Unless there is clarification and stabilization of the role, she is to play in rearing her children, she will be faced with demands and crises that adversely affect her ability to utilize the institutional program or successfully complete parole.

2. To facilitate the mother in working through her feelings about her chiloren, there must be a resource available to the women who d oes not report to the Program Planning Committee.

3. Obviously the prison enviromment is not the ideal setting for "grief work", but that does not mean the process should be ignored. Working through the impact of the separation requires an expression of high emotional content which initially might be disturbing to the inmate and the staff. The utilization of the confidential resource as mentioned in recommendation number two would enable the women to work out their feelings within the parameters of a supportive, non-judgmental relationship. The following model is a combination of methods used to help people through the grief process. It has been slightly modified to encompass, the dynamics of involuntary separation.

1. Help the mother accept the pain that is a part of the separation.

2. Review the mother-child relationship with the mother in light of its dymamic history and current meaning for the mother.

3. Help the mother deal with any change in her feelings she may be experiencing toward her 
child.

4. Help the mother dea] with her hostility and anger.

5. Encourage the mother to express her feelings of grief---it's a natural response to loss.

6. Help the mother to deal realistically with her present relationship with her child. An up-front approach in this area will discourage idealistic and fantasy-based planning.

It must be remembered that while this is a general outline, the process for each woman will be highly individualistic. Each woman will approach it differently depending on her cultural perspective as well as on her personal perceptions regarding the meaning of her relationship with her children.

4. Ioss of autonomy is one of the most difficult aspects of incarceration. A significant correlary to this for the inmate-mother is the loss of involvement in her child's care. The most dramatic hardship appears to be for mothers whose children are in foster care. Increased invol vement, largely through more active coordination with C.S.D is essential for the eventual mother-child reunion. Should it be determined that the mother's rights to her children are to be terminated, the mother's involvement is still crucial for the over-all adjustment of the child. Additionally, the staff should help those mothers whose children are living with relatives to become aware of some of the difficulties that may arise when they are reunited. When it comes time for the mother to resume her place in the family, she may find resistance by those who have cared for her child in her absence. If she is prepared, and understands the resistance and/or reluctance of the caretaker to disengage from the temporary role he or she has played, then there will be less difficul ty 
for all those involved in the reunion.

5. It has been suggested previously in this study that visits are an integral part of mother-child bond maintenance. Recommendations in this area are two-fold; one is directed to the community at large, and the other pertains to the Correctional Center's responsibility:

a) Comminity involvement in arranging transportation for the families of the residents to the center.

b) Awareness by the staff that mothers who must depend on non-family members (foster parents, C.S.D. workers) to bring their children for visits meet with a great deal of resistance. In such cases, it is the responsibility of the Correctional Center to strongly encourage more frequent visits. A mother should not be denied visits from her children simply because the state is providing care for her child while she is incarcerated.

\section{TMPI ICATIONS FOR RESEARCH}

The recommendations of the previous section were designed to be practical and feasible for use within the current prison structure. Should society choose to contimue to separate convicted women through incarceration, further research on the issues raised in this study would be needed. This would include repeated studies examining the effects of enforced separation on the mother's perception of her role, her emotional adjustment to the loss and the resulting repercussions on her relationship with her child. Replications would validate our exploratory results and lead to a clearer understanding of the effects of imprisonment on the mother-child bond. Verification of the range of emotions and research into the somatic distress associated with the grief process would be helpful to prison personnel and agencies involved in assessing a woman's relationship with her child. Such a definitive knowledge of probable 
reactions would serve as a guide for those assisting the inmate mother toward suitable resolution of her grief so that she can more realistically plan and make decisions regarding her children.

Upon implementation of the recommendations, research is needed comparing the effects on the maternal bond between those women who are given a specific forum to work through their grief process of loss and those who are not given a supportive framework. Longitudinal follow-up of mothers after release would shed information on the quality and adaptiveness of the reunion with their children. Such studies would inftiate a more balanced perspective by agencies and systems in examining parental needs and rights alongside that of children's needs and rights. Awareness of the reciprocity of these can no longer be ignored.

However, several factors would suggest that investigation of alternative methods of dealing with the inmate mother is needed. First, the high degree of concern for maintenance of a close relationship shown by the women interviewed in this study indicates that there is a capacity for growth through nurturance of the relationship. Secondly, current knowledge of the needs of children, especially those in the formative years would indicate the priority of keeping the mother and child together for the emotional well-being and development of the child. It may well be that rehabilitation of the inmate is more realistic if its focus is on the woman in the role she perceives as primary, be it the mother role or the work role.

Future research might explore alternatives to the current system such as various designs of nursery care within the current system or maintenance of the family in smaller units in the community with close supervision etc. Such changes would eliminate the separation itself. 


\section{FOOTNOTES}

1. Sykes, Gresham M. The Society of Captives: A Study of Yadimum Security Prisons Princeton: Princeton University Press: 1958 pp. 65-78

2. Burkhart, Katherine Women in Prison New York: Doubleday \& Company, Inc., 1973, p. 73

3. Giallombardo, Rose Society of Women: A Study of Women's Prison New York: John Wiley sons, Inc.; 1966 pp. 134-135

1. Bowlby, John "Separation Anxiety" in International Journal of Psycho-Analysis Vol. 4I, 1960 pp. 89-113

5. Lindemann, Erich "Symptomatology and Management of Acute Grief" in Crisis Intervention: Selected Readings: H. J. Parad, Ed: pp. $7-21$

6. Kübler-Ross, E. On Death and Dying New York: Macmillan Publishing Co., Inc. 1973

7. Bowlby, J. "Separation Anxiety" A Critical Review of the Literature" Attachment and Loss Vol. II, New York: Basic Books 1973 pp. $379-398$

8. Goldstein, F., Freud, A. \& Solnit, A. J. Beyond the Best Interests of the Child New York: Free Press, 1973

9. Freud, Clarice "Meaning of Separation to Parents and Children as Seen in Child Placement" Public Welfare XII Jan. 1955; pp. 1317,25

10. Britton, Clara "Casework Techniques in Child Care Services", Social Casework Vol. 36, Jan. 1955; p. 15

11. Smith, E. A., Ricketts, B. M. \& Smith, S. H. "The Recomendation for Child Placement by a Psychiatric Clinic" American Journal of Orthopsychiatry Vol. 32, Jan. 1962; pp. 43-49

$\checkmark$ 12. Mandelbaum, Arthur "Parent-Child Separation: Its Significance to Parents" Social Work VII, Oct. 1962; pp. 26-34

13. Jenkins, Shirley \& Norman, Elaine Filial Deprivation \& Foster Care New York. Columbia Uni versity Press, 1972

V 14. Prugh, D. G. \& Harlow, R. "'Masked Deprivation' of Infants and Young Children" Deprivation of Maternal Care John Bowlby, ed. New York: Schocken Books; 1967: p. 215 
15. Benedek, Therese "A Psychobiologic Approach to Parenthood" in Parenthood: Its Psychology and Its Psychopathology James Anthony and Therese Benedek, ed. Boston: Litte, Brown and Company. 1970 : pp. $109-185$

16. Jenkins, Shirley, and Norman, Elaine. Fillal Deprivation and Foster Care New York: Columbla University Press, 1972

17. Benedek, op. cit.

18. Burkahrt, Katherine Women in Prison, op. cit.

19. Giallombardo, Rose Soclety of Women op. cit.

20. Eyman, J. S. Prisons for Women Ilinois: Charles C. Thomas, Pub., 1971

21. Ward, D. A. \& Kassebaum, G. G. Women's Prison: Sex and Social Structure Chicago: Aldine Company. 1965

22. Velimesis, Margery. "Criminal Justice for the Female offender", AAUW Journal Oct. $1969 ; \mathrm{pp} \cdot 13-16$

23. Zalba, S. R. Women Prisoners and Their Families Los Angeles: DelMar Company, Inc. 1964

24. Eyman, op. cit.

25. Burkhart, op. cit.

26. Benedek, Therese, :Motherhood and Nurturing: in Parenthood, Ed. by E. James Anthony, M.D., D.P.M. \& Therese Benedek. op. cit. p. 153

27. Ward, David A. and Gene G. Kassebaum, op. cit. p. 15

28. Ibid, $p \cdot 70$

29. Giollombardo, Rose, "Social Roles in a Prison for Women"Social Problems $13: 3$, Winter 1966; p. 270

30. Bird, Caroline, "The Sex Map of the Work World", in Roles Women Play: Readings Toward Women's Liberation, ed. by Milchele Hoffung Garskof, Belmont, California: Brooks/Cole Publishing Co., 1971; p. 53

31. Minuchin, Salvador, et. al. Families of the Slums, New York: Basic Books, Inc. 1967; F. 152

32. Dixon, Marlene, "Why Women's Liberation" in Garskof, op. cit. p. 165

33. Zalba, Serapia R. Women Inmates and Their Families, Los Angeles: Delmar Publishing co. 1964; p. 3 
W34. Rutter, Michael Maternal Deprivation Reassessed England: Penquin Books Itd. 1972; p. 17

35. Clark, H. H. Jr. The Law of Domestic Relations in the United States St. Paul, Minn.: West Publishing Co., 1968; chaps. 17

36. Sykes, op. c1t., p. 65-78

37. Mandelbaum, op. c1t. p. 30

38. Sykes, op. cit.

39. Burkhart, op. cit.

40. Kubler-Ross, op. cit., p. 85-86

41. Chesler, Phylis, Women in Madness New York: Avon Books; p. 64

14. Kubler-Ross, op. c1t., p. 52

43. Freud, Clarice, op. cit., p. 15

44. Lindemann, op. cit., p. 9

45. Goldstein, op. cit., p. 40

46. Lindemann, op. cit. p. 9

- 47. Thomas, Carolyn B. "The Resolution of Object Loss Following Foster Home Placement" Smith College Studies in Soclal Work XXXVII June 1967; pp. $163-234$

48. Simmons, G., Gupert, J. and Rothman, B. "Natural Parents as Partner in Child Care Placement" Social Casework April 1973; pp. 224-232

49. Giallombardo, Rose, op. cit. pp. 134-135

50. Galtung, John "Prison: The Organization of Dilemma" in Ward \& Kassebaum's Women's Prison p. 19

51. Ward \& Kassebaum, op. cit. p. 19

52. Uniform Crime Reports, F.B.I., Washington D. C. 1974

53. Farr, Kathy, Theoretical Perspectives on the Nature of Female Crime Unpublished Manuscript, Portland State University, 1974; p. 13 


\section{BIBLIOARAPHY}

\section{PRISON LITERATURE}

American Association of University Women, Pennsylvania Iivision. Report on the Survey of 41 Pennsylvania County Court and Correctional Services for Women and Girl Offenders, Jan. 1, 1965 - Dec. 31, 1966, Fhiladelphia, 1969

Balchen, Bess, "Prisons: The Changing Outside View of the Inside" AIA JOURNAL, Sept. 1971

Burkhart, Kathryn, Women in Prison New York: Doubleday \& Company, Inc., 1973

Cunningham, Gloria, "Supervision of the Female Offender", Federal Probation XXVIII, Dec. 1963

Deming, Barbara, Prison Notes, New York: Grossman Pubs., 1966

Eyman, Joy, Prisons for Women. A Practical Quide to Administration Problems, Springfield, III.: C.C. Thomas, 1971

Geller, William, "The Problems of Prisons---A Way Out?" The Humantst, Ethical Forum, May-June 1972

Giallombardo, Rose, Soclety of Women. A Study of a Women's Prison, New York: Wiley 1966

$\checkmark$ Goffman, Erving, Asylums, Garden City, New York: Doublday 1961

Harmon, Sasha, "Attitudes Toward Women in the Criminal Process", UnpubIished paper available in Yale I aw Iibrary 1970

Haslam, Phyllis, "The Female Prisoner", The Canadian Journal of Corrections, $6(4), 1964$ pp. 463-466

Henry, Joan, Women in Prison, New York: Doubleday 1952

Kanowitz, Leo Women and the Law, Albuquerque: Univ. of New Mexico Fress, $196 \overline{9}$

I ekkerkerker, Eugenia, Reformatories for Women in the United States, Batavia: T.B. Wolters, 1931

Minton, Robert, Inside:Prison American Style, New York: Random House 1971 
Mitchell, Arlene, Informal Inmate Social Structure in Prisons for Women: A Comparative Study, Ph. D. Dissertation, University of Washington. 1969. Ann Arbor, Michigan: University Microftlms, Inc., 1969

Mitford, Jessica, "Experlemnts Behand Bars", Atlantic Monthly, Jan. 1973 , "Kind and Usual Punishment in California", Atlantic Monthly, March 1971

Parker, Tony, Women in Crime: Five Revealing Cases, New York: Delta Books, 1968

Follock, Otto, The Criminality of Women, Philadelphia: Univ. of Pa. Press 1950

Reckless, Walter C., and Day, Barbara Ann, The Female offender unpublished paper submitted to the President's Commission on Law Enforcement and the Administration of Justice, 1967

Shepard, Dean and Zemans, Eugene S., Prison Babies, Chicago: John Howard 1950

Smith, Ann D., Women in Prison, London: Stevens, 1962

Sykes, Gresham M., Crime and Society, New York: Random House, 1967

- The Society of Captives: A Study of Maximum Security Prisons, New Jersey: Princeton University Press, 1958

Velimesis, Margery I., "Criminal Justice for the Female Offender", Journal of the American Association of University Women, October 1969

Ward, David A., and Kassebaum, Gene, Women's Prison: Sex and Social Structure, Chicago: Aldine Pub., 1965

Zalba, Serapla R., Women Immates and Their Families, Los Angeles: Delmar 1964

LOSS ANI GRIEF LITERATURE

Anderson, B. G., Bereavement as a Subject of Cross-Gultural Inquiry: An American Sample", Anthropological Quarterly, 33:181, 1965

Anderson, C., "Aspects of Pathological Grief and Mourning", International Journal of Psychoanalysis, 30:48, 1949

Bamacle, C.H., "Grief Reactions and Their Treatment", Diseases of the Nervous System, 10:173, 1949 
Becker, H., "The Sorrow of Bereavement", Journal of Abnormal and Soctal Psychology, 27:391, 1933

Bowlby, John, "Grief and Mourning in Infancy and Early Childhood", Psychoanalytical Study of the Child, 15:9, 1960
, "Process of Mourning", International Journal of Psycho- analysis, $42: 317,1961$

, "Pathological Mourning and Chtldhood Mourning", Journal of the American Psychoanalytic Association, 11:500, 1963

Deutch, H., "Absence of Grief", Psychoanalytic Quarterly, 4:12, 1937

Enge1, G.I., "Is Grief I1sease?", Psychosomatic Medicine, 23:18, 1961 , "Grief and Orieving", American Journal of Nursing, 64:93, 1964

Freud, S., "Mourning and Melancholia", (1917) Complete Works XIV, Standard Edition, London: Hogarth 1953

Greene, W.A., "Role of a Vicarious Object in the Adaption to Object Loss: I. Use of a Vicarfous Object as a Means of Adjustment to Separation from a Significant Person", Psychosomatic Medicine, 20:344, 1958

Kalish, R.A., "Dealing with the Grieving Family", R.N., 26:81, 1963

- Krupp, G.R., "The Bereavement Reaction: A Special Case of Separation Anxiety---Sociocultural Considerations", Psychoanalytic Study of Society, 2:42, 1962

Kubler-Ross, E., On Death and Dying, New York: Macmillan Publishing Co, Inc., 1973

Iindemann, Erich, "Symptomatology and Management of Acute Grief", American Journal of Psychiatry, 101"141, 1944

Parker, C.M., "Grief as an IIness", New Society, April 1964

- Pollock, G.H., "Mourning and Adaption", International Journal of PsychoAnalysis, $42: 341,1961$

Schoenberg, Bernard, M.I., et al, Loss and Grief: Psychological Management in Medical Practice, New York and London: Columbia Univ. Press 1970

$\therefore$ Siggins, I., "Mourning: A Critical Survey of the Iiterature", International Journal of Psychoanalysis, 47:14, 1966

- Stern, K., G.M. Williams and M. Prados, "Grief Reactions in Iater Iife", American Journal of Psychiatry, 108:289, 1951 
SEPARATION LITERATURE

$\rightarrow$ Ainsworth, Mary D., Ieprivation of Maternal Care: A Reassessment of Its Effects, Generva, World Health Organization, 1962

Apteckar, Herbert H., Casework with the Child's Own Family in Child Placing Agencies, New York, Child Welfare League of America, 1963

Benedek, Therese and James Anthony, ed., Parenthood: Its Psychology and its Psychopathology, Boston: Iittle, Brown and Company, 1970

Bowl by, John, "Separation Anxiety", International Journal of Psychoanalysis, Vol. 41, 1960

, Maternal Care and Mental Health, Geneva, World Health Organization, 1952

$\longrightarrow$ - - "Separation Anxiety: A Critical Review of the Itterature", Attachment and Loss, Vol. II, New York: Basic Books, 1973

Britton, Clara, "Casework Techniques in Child Care Services", Social Casework, Vol. 36, Jan. 1955

Freud, Clarice, "Meaning of Separation to Parents and Children as Seen in Child Placement", Public Welfare XII, Jan. 1955

$\checkmark$ Glickman, Esther, "Treatment of the Child and His Family After Placement", Social Service Review, XXVIII, Sept. 1954

Goldstein, F., Freud, A. and Solnit, A.J., Beyond the Best Interests of the Child, New York: Free Press 1973

Hutchinson, Dorothy, "The Request for Placement Has Meaning", Social Casework, XXV, June 1944

Jenkins, Shirley, "Duration of Foster Care---Some Relevant Antecedent Variables", Child Welfare, October 1967 \begin{tabular}{l} 
Care", "Filial Deprivation in Parents of Children in Foster \\
\hline Jan. - Feb. 1967
\end{tabular}

"Separation Experiences of Parents Whose Children are in Foster Care", Child Welfare, June 1969

Filial Deprivation and Foster Care, New York: Columbia University fress, 1973

Mandelbaum, Arthur, "Parent-Child Separation: Its Significance to Parents", Social Work, VII, October 1962 
Prifh, J.r. and Har] ow, R., "Masked Jeprivation of Infants and Young Chiluren", Ieprivation of Maternal Care, John Bowlby, ed., New York: Schocken Books, 1967

Rheingold, Harriet I., ed., Maternal Behavior in Mammals, New York: John Wiley, 1963

Rutter, Michael, Maternal Deprivation Reassessed, England: Penquin Books, Inc., I972

Simmons, G.., Gupert, J. and Rothman, B., Natural Parents as Partners in Child Care Placement", Social Casework, April, 1973

Smith, E.A., Ricketts, B.M. and Smith, S.H., "The Recommendation for Child Flacement by a Psychiatric Clinic", American Journal of Orthopsychiatry, Vol. 32, Jan. 1962

Thomas, Carolyn B., "The Resolution of Object Ioss Following Foster Home PIacement", Smith College Studies in Social Work, XXXVIII, June, 1967

$\checkmark$ Young, Ieontjne R., Separation: Its Meaning to the Child, the Parents and the Community, New York State Conference of Social Work Proceedings 1943-1945, Annual Vol. 1945 
APPENDTCES

A. TNTRODUCTION TO QUESTIONNATRE

B. QUESTIONNATRE

C. QUESTIONNAIRE FOR THE SUPFRTNTENDENT OF OWCC

D. QUESTIONNAIRE FOR THE C.S.D. IIAISON WORKER

E. OREGON IAW REGARDTIG PARTNTAI RIGHTS 
APPENDIX A

SUGGESTED INTRODUCTCRY EXPLANATION

My name is __ and I'm a graduate student at Portland state University. We are doing research in the area of women in prison. Specifically we are interested in the experiences of mothers who are separated from their children. Very little research has been done in this area and we feel that the problems of mothexs in prison have been largely unexplored. We are going to be asking you questions about your experiences and we hope that what we learn can be used to bring about some changes that will help you and other women in your situation. We really appreciate that you agreed to be interviewed.

One thing that we are concerned about, and I know you must be too, is confidentiality. I don't know your name and what I write down will not be connected with you or your records. If there are any questions that you don't want to answer, that's fine. The interview will take about 45 minutes to an hour. Do you have any questions before we begin? 


\section{QUESTIONNAIRE}

Dorothy Lundberg

Ann Sheekley

Therese Voelker

1. How old are you?

2. How many children do you have?

3. What are their ages?

4. I'n going to ask you a few questions about any marriages you've had or relationships you've had, and how these all relate to your children:

Are you married?

Ies: Have you been married before?

How many times?

How long did the relationships last?

No: Have you ever been married?

Have you ever had any long-standing relationships with men? How long?

Do all the childron have the same father?

Could you describe your relationship in a few worde?

-How did you get along?

lBt:

2nd: 
How was the relationship of the father (significant wen) with the children?

-Was he involved with them?.

-Was their relationship part of your problems?

5. How long have you been here at the Correctional Center?

How long have you been away from your children? (since arreat)

6. Were you living with your chlldren before you were incarcerated?

No: Can you tell me what the situation was then?

7. How long do jou expect to be here?

-When do you expect to be released?

8. What are you in for?

-Charge?

9. Have your children ever been away from you for any length of time?

Yes: How many times?

For how long?

What was the reason?

How did you and your klds get back together? (motive)

Were any of these because you were in prison? 
10. Now I'm going to talk a bit about your own experiences as a child.

In your own childhood, were you ever away from you mother or father for any length of time?

Yes: How many times?

How old were you?

For how long?

Was there any time that you

remember being the hardest?

Were you ever in foster home os inotitution?:-

11. Were you working before your arrest?

Yes: What kind of work did you do?

What kind of work have you done?

No: Have you ever worked?

What kind of work have you done?

12. Did you like your job?

Would you go back to it? 
13. Did you earn enough money to make 1t?

14. What kind of work do you think you'll be doing when you get out? -What you'd like to do?

-What you 11 probably do?

15. How far did you get in school?

16. Are you recelving any training here? If so, what?

17. I am going to hand you a card on which are listed a number of things you may find yourself thinking about here.

-Read through all the items. Find the one that you worry or concern yourself about the most. Put "I" next to the number.

-Now find the one that you worry or concern yourself about second most. Put a "2" next to the number.

-Now find the one that worries or concerns you third most. Put a "3" next to the number.

1. Ending up in here again

2. Being able to make it on the outside

3. Missing fyy friends and the action outside

4. Being away from my man

5. Getting along with the other women here

6. Being away from my children

7. Getting along with the rules and regulations here

8. Keeping my head together here

9. Worrying about how ey childron are doing 10. Other 
18. Where are your chlldren now?

19. Did you have any say in where they wore placed?

20. Are you satisfied with where your children are? -Could you explain that?

21. Do you feel that your children are well taken care of? -Would you tell me a bit more about that? -Can you give me any examples? (emotional-material)

22. Do you have any say in how your children are being cared for while you are here?

-In what areas?

- Regular or seldom occurrence?

23. Do you get news about your children?

Yes: From whom?

How oftex?

Is this contact by letter, telephone or visit?

What is this news about? 
24. Do your children know where you are?

Who told them?

25. What explanation were they given?

26. Are you satisfied with the explanation that was given to your children?

27. Do you and your children talk about the explanation now?

\section{Yes: How often?}

28. Do you think that all the people involved with your children are giving the same explanation?

No: Could you tell me how they differ?

29. How often do you see your children?

30. Are you satisfied with the number of visits?

(If an expediency answer is given, ask:) If that barrier didn't exist; would you be satisfied?

No: Is there anything you can do about it?

31. Who decides if your children come to visit you? 
32. How would you feel about a day care setting at the prison for the younger childred of mothers here?

33. Many people feel a variety of emotions about being separated from their children. Put a check by any of the feelings you have had regarding any part of the experience of being away from your children. (hand over list)

After you check the emotions you have felt, I w1ll ask you what you felt angry about, what you fel worried about? This may help you in making your selection.

What did you feel.....

ANGRY about:

BITTER about:

REIEVED about:

THANKFUL about:

WORRIED about:

NERVOUS about:

ASHAMED about:

GUILTY about:

PARALYZED about: 
What did you feel.....

EMPTY about:

NUMB about:

RESENTFUL about:

HELPLESS about:

AFRAID about:

34. These are some concerns that mothers who are away from their children have expressed. (Hand woman set of cards)

-First take out the cards that don't apply to you.

-Now look through the cards and find the one that concerns you most. Try to put the rest of them in order-your second concern, your third, etc.

Will my child remember me?

Will my child love me?

Will my child think that the person who is taking care of him/her is a better mother than $I$ am?

W1ll my child become more attached to the person who is taking care of hidher than he/she is to me?

will my child be able to respect me after this?

Will the person who is taking care of my child

turn my child against me?

Will I feel like keoping house and taking care of wy child when I got out?

Will I be able to work and support my child?

Will I be able to talk about being in prison with my ohild when I get out?

Will my child be taken from me? 
35. This last section involves some open-ended questions around several areas. I'd like you to foel free in talking as much as you wan about the subjeet.

Tell me what you visits with your children are like?

What do you do?

What kind of things do you talk about?

Does the person who brought the children leave them alone with you?

Do you get time alone with each child?

Obviously it is different to be with your child here than at home where you are with your children all the time. Could you talk about the differences? 
After the visit is over how do you feel?

You have been away from your children for a while. How do you feel this will affect your ablitty as a parent?

-Some people think that after time away, they lopes touch with some of the ways they deal with children. Is this so for you? In what way?

What do you see as the major problems coming out of being away from your kids? 
$-11-$

36. Interviewer's impressions of interviewee: 
APPENDIX C

Questionnaire for superintendent of OWCC

I. Could you give us an historical perspecitve of owCC?

A. What changes have occurred in the prison in terms of conditions, rehabilitation, parole policies, etc., since its beginning?

B. Have changes occurred in the Integrated Services Project since its inception in 1972 ?

II. Could you give us a description of your job responsibilities?

A. What is the percentage breakdown of time spent in public relations as opposed to in-house functions?

B. Could you explain the flow of command chain at OWCC?

IJI. What are the determining factors that bring a woman to OWCC?

A. What types of criminal offenses result in incarceration at a state prison as opposed to incarceration at the county jail?

B. What is the percentage breakdown of state and federal offenders?

C. Are there any out-of-state women at OWCC?

I. Have there been any changes in the type of women sentenced here over the years?

IV. What are the goals of rehabilitation?

A. What is your philosophy of rehabilitation?

B. Is there an individualized rehabilitation plan for each woman?

C. Who develops the plan?

D. Does the woman have input in planning her program?

E. Do you feel there is a dis crepancy between the goals that a woman may have formulated for herself and those she formulates in rehabilitation planning? (Do women carry out the goals for the purpose of satisfying the Parole Board or are they internalized?)

F. What type of goals are included in a woman's rehabilitation plan? (Job related, personal? How are each weighted?)

G. How are the goals of rehabilitation achieved?

H. Through what areas of rehabilitation does the most amount of change sccur, through job training, counseling, parole requirements?

I. What do you see as the biggest obstacles in achieving the goals of rehabilitation?

V. How does the Parole Board work?

A. Who composes the Farole Board?

B. Is it the job of the Parole Board to evaluate a woman's progress on her rehabilitation plan---or how does that work?

C. Who submits progress reports on the women?

D. How are the various factors in the rehabilitation plan weighted?

E. How are the "attitudes" of a woman evaluated?

F. What kind of feedback is given women whose farole has been postponed? 
G. Does age or placement of a woman's children affect parole decisions?

VI. How do you perceive the future trends for women in the criminal justice system? What is happending right $n$ ow in terms of change?

VIT. How would you feel about a day-care setting at the prison for the younger children of mothers here? 
APPENDIX D

\section{Questionnaire for CSD Liaison Worker}

I. Could you give us a description of your job responsibilities?

A. What is the percentage breakdown of your job?

B. How much time is spent with women associated with CSD as opposed to other women?

C. As a member of the Integrated Services Core team, how do you facilitate a woman's transition back into her mother role after she leaves OwCC?

D. Are you a member of the Parole Board?

E. What role do you play in the decisions of the Parole Board?

F. Do you provide the Parole Board with progress reports on women you deal with?

II. What positions are there here other than the custodial positions? (counselors, psychologists, etc.)

A. What are their responsibilities?

B. How much time do they spend in the prison?

C. Are their services bought or voluntary?

D. What is their sex?

E. What individual, group and marital counseling is available?

F. Who does individual counseling, marital, and group counseling?

G. How is it decided whether a woman joins a group, has individual or marital counseling?

H. Is counseling or group participation usually included as part of a woman's rehabilitation plan?

I. What problems are usually brought to individual, group, or marital counseling?

$\mathrm{J}$. Is there a processof orientation for new women entering OWCC?

III. What are the mules regarding visits?

A. Is there a set policy determining when a woman can have her first visit and subsequent visits?

B. How is a list of permitted visitors determined?

C. Are there any regulations regarding phone calls, passes or letters?

D. Are there ever any restrictions placed on visits, passes, etc.?

IV. What do you see as the goals of rehabilitation?

A. Do you participate in the formulation of rehabilitation plans?

B. How are the goals of rehabilitation achieved?

C. Through what areas of rehabilitation does the most amount of change occur; through job training, counseling, parole requirements?

D. What do you see as the biggest obstacles in achieving goals of rehabilitation?

E. Does the age or placement of a woman's children affect her parole decision? 
V. What kinds of special programs are offered to women with children?

VI. How do you perceive the future trends for women in the criminal justice system? What is happening right now in terms of change?

VIT. How would you feel about a day-care setting at the prison for the younger children of the mothers here? 
sufficient by the court; but, uniess the parent not having custody consents to the adoption, a citation to ahow cause why the proposed adoption shall not be made shall be served in accordance with ORS 109.330 upon the parent not having the custody, and the objections of such parent shall be heard if apperrance is made. This section does not apply where consent is given in loco parentis under ORS 109.316 or 109.318 .

[1957 c.710 \$3 (ORS 109.312 to 109.329 enacted in lieu of Ors 109.320)]

109.316 Consent by Chlldren's Services Division or an approved child-caring ageray of this state. (1) The Children's Je:vices Division or an approved child-caring agency of this state, acting in loco parentis, may consent to the adoption of a child who has been:

(a) Surrendered to it for the purpose of adoption under ORS 418.270 if compliance is had with the provisions of that section; or

(b) Permanently committed to it by order of a court of competent jurisdiction; or

(c) Surrendered to it for the purpose of adoption under ORS 418.270 by one parent If compliance is had with the provisions of that cantinn and nommonantly snommittad tn It by a court of competent jurisdiction having jurisdiction of the other parent.

(2) Where consent is given under this section, no other consent is required.

(9) Where consent is given under this section, there shall be filed in the adoption proceeding:

(a) A certiffed copy of an order of a court of competent jurisdiction fomilly and permanently assigning the guardianenip of the child to the division or the child-caring agency, or a copy of the surrender of the child from its parent or parents or guardian, or both, as the case may be; and

(b) Written formal consent by the division or the child-caring agency, as the case may be, to the proposed adoption, showing that sufficient and satisfactory investigation of the adopting parties has been made and recommending that the adoption be granted. The consent of the division or the child-caring agency to the proposed adoption may be giver by one of its officers, executives or employes who has been authorized or designated by it for that purpose.

[1957 c.710 \$ (109.312 to 109.328 enacted in lieu of 200.320); 1071 c.401 85]
-

109.318 Consent by organisstion loosted outside Ocegon. (1) An agency or other organization, public or private, located entirely outside of this state, or an suthorised officer or executive thervol, acting in 1000 parentis, may consent to the adoption of a child unter its of his custody, control or guardianship, if such agency or organizatipa or officer or executive thereof is licensed or otherwise has authority in the juriadiction in which such agency or other organization is located to consent to adoptions in loco parentis. When consent is given under this rection, no other consent is required. The license or other authority to consent to edoption in loco parentis shall be conclusively presumed upon the filing with the court of a duly certified statement from an appropriate governmental agency of such other state that such agency or organization or officer or executive is licensed or otherwise has authority in. such state to consent to adoptions in loco par entis.

(2) Where consent is given under this section, there shall be filed in the adoption proceeding:

(a) A certified copy of the court crider, or the written authorization from the parent, parents or other person, or both court nrrier and sure written al:thomzation. as the case may be, that enables consent to be given in loco parentis under the law of auch other jurisdiction; and

(b) Written formal consent by the agency or other organization, or the officer or executive thereof, to the proposed adoption, showing that sufficient and satisfactory investigation of the adopting parties has been made and recommending that the adoption to granted.

[1957 c.710 \$5 (109.312 to 108.328 enacted in lieu of 103.320); 1873 c.823 \$107]

109.320 [Repealed by 1957 c.710 \&1 (109.312 to 109.329 enacted in lleu of 109.820)]

109.322 Consent where parent mentally ili, mentally deflalent or imprisoned. If either parent has been adjudged mentally ill or mentally deficient and remains 80 at the time of the adoption proceedings, or in imprisoned in a state or federal prison uncer a sentence for a term of not less than three years, there shail be served upon such parent, If he has not consented in writing to the adoption, a citation in accordance with ORs 102.330 to show cause why the adoption of the shild should not be decreed. In the case of a person adjudged mentally ill or mentally deficient, the citation shall also be carred 
upon the guardian of his person or, if he has no guardian of the person, the court shall appoint a guardian ad litem to appear for the person in the adoption proceedings. Upon bearing being had, if the court finds that the welfare of the child will be best promoted through the adoption of the child, the consent of the mentally ill, mentally deficient or imprisoned parent is not required, and the court shall have authority to proceed regardless of the objection of such parent. This section does not apply where consent is given in loco parentis under ORS 109.316 or 109.318 .

[1057 c.710 \$6 (109.312 to 109.329 enacted in lieu of 108.320)]

109.324 Consent where parent has dosorted or neglected child. If either parent is believed to have wilfully deserted or neg: lected without just and sufficient cause to provide proper care and maintenance for the child for one year next preceding the filling of the petition for adoption and such parent does not consent in writing to the adoption, there shall be served upon such parent a citation in accordance with ORS 109.330 to show cause why the adoption of the child should not be decreed. Upon hearing being had, if the court finds that such

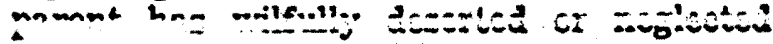

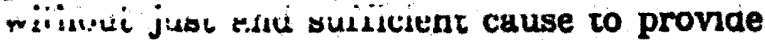
proper care and maintenance for the child for one year next preceding the filing of the petition for adoption, the consent of such parent at the discretion of the court is not required and, if the court determines that such consent is not required, the court shall have authority to proceed regardless of the objection of such parent. In determining whether the parent has wilfully deserted or neglected without just and sufficient cause to provide proper care and maintenance for the child, the court may disregard incidental visitations, communications and contributions. This section does not apply where consent is given in loco parentis under ORS 109.316 or 109.318 .

[1957 c.710 \$7 (108.312 to 109.329 enacted in lieu of $\{00.320)\}$

109.326 Consent where parents not marrled to each other. (1) The consent of the mother of the child is sufficient, and for the purpose of giving such consent the mother of the child shall be deemed to have arrived at the age of majority and for all purposes relating to the adoption of the child the father of the child shall be disregarded just as if he were dead, when it is shown in the court in which the adoption prosecellnga aro pending that:

(a) The mother of the child was unmarried at the time of the conception of the child to be adopted and remained unmarried at the time of the birth of the child and was not married to the father of the child at the time of her consent to the adoption or aurrender of the child for the purpose of adoption under ORS 418.270; or

(b) When the mother of the child was married at the time of the conception or birth of the child, and it has been judicially determined that her husband at such time or timers was not the father of the child. Such. determination of nonpaternity may be made by any court having adoption or juvenile court jurisdiction. The testimony or affidavit of the mother or such husband shall constitute competent evidence before the court making such determination. Before making such determination of nonpaternity, citation to show cause why such husband's parental rights should not be terminated shall be served on him personally, if found in the state, and if not found in the state, then a copy of the citation shall be published or served in the manner provided by ORS 15.110 to 15.140 for the service of citation by

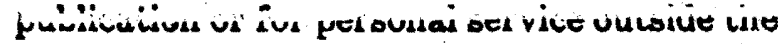
state; except that the citation so seired by publication need not contain the names of the adoptive parents.

(2) If the mother described in subsection (1) of this section is dead or unknown, consent shall be obtained in the same manner as if such child had no living parent.

[1957 c.710 \&8 (109.312 to 109.329 enacted in liou of 109.320); 1958 c.609 §1; 1967 c.385 §1; 1969 c.691 §287]

109.828 Child 14 years of age or older must also consent. If the child is 14 years of age or older, the adoption shall not be made without his consent. The consent required by this section is in addition to, and not in lieu of, the consent otherwise required - by law.

[1957 c.710 \$9 (109.312 to 109.328 enacted in lieu of (09.320)]

109.329 Consent where person to be adopted has reached age of majority. If the person to be adopted is legally married or is 18 years of age or older, his written consent may be held by the court to be sufficient without the necessity for the consent of any other person to the adoption.

[1857 c.710 \$10 (109.312 to 109.329 enacted in lieu of 108.320); 1973 c.827 §13] 
HOUSE BILL 2797

\section{A BILL FOR AN ACT}

Relating to termination of parental rights; amending ORS 419.523 .

Be It Inacted by the People of the state of oregon:

Section 1. ORS 419.523 is amendeci to read:

419.523. (1) The parental rights of the parents of a child within the jurisdiction of the juvenile court as provided in subsection (1) of ORS 419.476 may be terminated as provided in this section and oRS 419.525. The rights of one parent may be terminated without affecting the right of the other parent.

(2) The rights of the parent or parents may be terminated as provided in subsection (1) of this section if the court finds that the parent or parents are unfit by reason of conduct or condition seriously detrimental to the child and integration of the child into the home of the parent or parents is improbable in the forseeable future due to conduct or conditions not likely to change. In determining such conduct and conditions, the court shall consider but is not limited to the following:

(a) Emutional illness, mental illness or mental deficiency of the parent of such duration as to render it impossible to care for the child for extended periods of time. 
Pag̣o 2

(b) Conduct toward any child of an abusive, cruel or sexual nature.

(c) Addictive use of intoxicating liquors or narcotic or dangerous dzugs.

(d) Physical neglect of the child.

(e) Lack of effort of the parent to adjust his circumstances; conduct, or conditions to make the return of the child possible or fá:lure of the parent to effect a lasting adjustment after reasonable efforts by available social agencies for such extended duration of time that it appears reasonable that no lasting adjustment can be effected.

(3) The rights of the parent or parents may be terminated as provided in subsection (1) of this section if the court finds that the parent or parents have failed or neglected without reasonable and lawful cause to provide for the basic physical and psychological needs of the child for one year prior to the filing of the petition. In determining such failure or neglect, the court shall consider but is not limited to one or more of the following:

(a) Failure to provide care of pay a reasonable portion of substitute physical care and maintenance if custody is lodged with others.

(b) Failure to maintain regular visitation or other coniact with the child which was designed and implemented in a plan to reunite the child with the parent. 
(c) Failure to contact or communicate with the child or with the custodian of the child. In making this determination, the court may disregard incidental visitations, communications or contributions.

(4) The rights of the parent or parents may be terminated as provided in subsection (1) of this section if the court finds that the parent or parents have abandoned the child or the child was left undus circumstances such that the identity of the parent or parents of the child was unknown and could not be ascertained, despite diligent searching, and the parent or parents have not come forward to claim the child within six months following the finding of the child. 